\title{
The Private Equity Negotiation Myth
}

\author{
William W. Clayton ${ }^{\dagger}$
}

Private equity fund agreements have been criticized for failing to protect investors from exploitation by fund managers. One defense frequently used by the industry has been to invoke what I call the private equity negotiation myth, which claims that because fund agreements are highly negotiated, substantive concerns about their terms are unwarranted. This myth assumes that large investors will use their bargaining power to demand strong fund agreement protections for all of the investors in a fund.

This Article questions the private equity negotiation myth. First, I show that large investors' incentives to negotiate fund agreements can often be weaker than the myth suggests. Because large private equity fund investors are commonly able to negotiate for individualized benefits outside of fund agreements, they have strong incentives to use their bargaining power to maximize individualized benefits before negotiating for better fund-wide protections. Individualized benefits thus can dampen the extent to which fund agreements are actually negotiated. Second, I show that large investors cannot always be expected to "vote with their feet," either, by avoiding funds with suboptimal protections. When large investors have bargaining power, it makes them less sensitive to the quality of fund agreement terms because they can negotiate for individualized benefits that offset the harm caused by weak protections. As a result, the marginal investors in private equity funds-those whose preferences have the greatest influence on the quality of fund termsmay sometimes be ones that lack bargaining power rather than the ones that have it. Lastly, some of the largest institutional investors in private equity funds may suffer from internal agency problems that reduce their incentives to demand strong protections.

The private equity negotiation myth thus encourages policymakers to make policy decisions based on incomplete information in this $\$ 5$ trillion industry. By challenging the myth and showing the true incentives associated with bargaining power in private equity funds, this Article contributes to

$\dagger$ Associate Professor, BYU Law School. I am thankful to Robert Daines, Elisabeth de Fontenay, Jessica Erickson, Jill Fisch, Jesse Fried, Michael Guttentag, Christine Hurt, Cathy Hwang, John Morley, Roberta Romano, Megan Shaner, Andrew Tuch, and participants in the "New Voices in Business Law" workshop at the 2019 Association of American Law Schools Annual Meeting, the "Perspectives on Cutting-Edge Issues in Venture Capital and Private Equity" workshop at the 2019 A.B.A. Business Law Section Annual Meeting, and the 2019 BYU Law Winter Deals Conference for helpful discussions and comments on earlier versions of this Article. All errors are my own. 
important and timely policy discussions at both the state and federal levels on the regulation of private investments.

Introduction 69

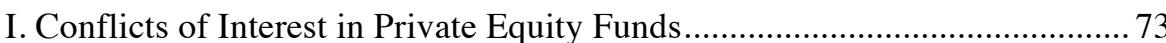

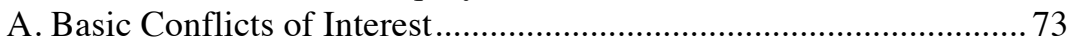

B. Protections Against Conflicts.......................................................... 75

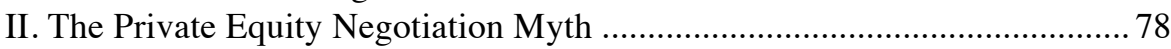

A. Critiques of Private Equity LPAs ................................................. 78

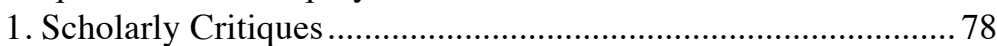

2. Journalistic Critiques ............................................................. 82

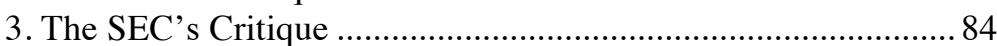

B. The Industry's Negotiation-Based Defense ……................................ 85

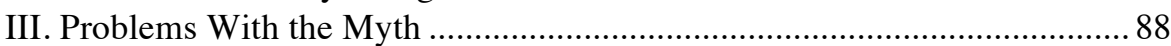

A. Large Investors Cannot Be Counted on to Negotiate LPAs ............. 89

1. Why Large Investors Have Bargaining Power............................ 89

2. Diminished Incentives to Negotiate LPA Terms ....................... 91

3. Most Important Protections Are Least Likely to Be

Negotiated When There Is Information Asymmetry ................ 96

B. Large Investors Cannot Be Counted on to Vote with Their Feet...... 97

1. How Contract Terms Are Shaped in the Absence of

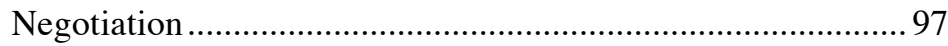

2. Large Investors Won't Always Be the Marginal Investors........ 98

C. Agency Problems Can Reduce Incentives to Demand Strong

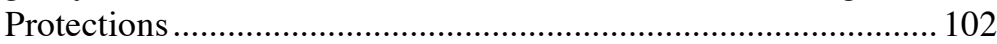

D. Forms of Individualized Benefits in Private Equity ........................ 103

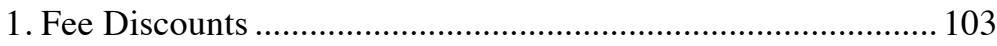

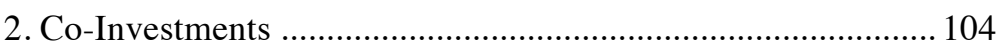

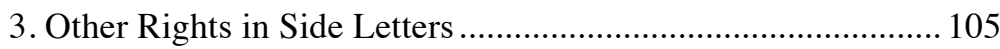

4. Separately Managed Accounts ................................................... 106

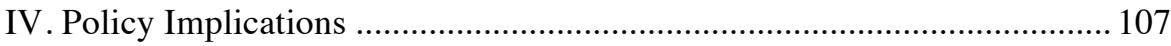

A. State Law: Waiving Fiduciary Duties in Limited Partnerships ...... 107

B. Federal Law: Regulating Access to Private Funds ........................... 110

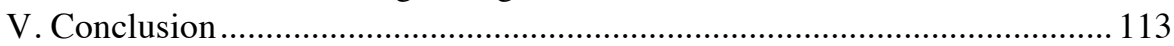

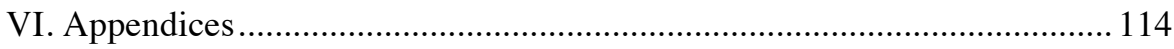


The Private Equity Negotiation Myth

Introduction

Strong criticisms have been levied against private equity fund agreements in recent years. Fund agreements have been accused of enabling managers to charge exorbitant fees, ${ }^{1}$ encouraging managers to engage in excessive risktaking, ${ }^{2}$ allowing managers to operate behind a veil of secrecy, ${ }^{3}$ and eliminating negative consequences for managers' bad behavior, ${ }^{4}$ among other critiques. One commentator has accused fund agreements of being so deficient that they create an "incubator for agency costs." Given the vast size of the private equity market, ${ }^{6}$ and the heavy investment by public institutions in private equity funds ${ }^{7}$ these criticisms have raised alarm.

In response, one defense frequently used by the private equity industry has been to invoke what I call the private equity negotiation myth. ${ }^{8}$ The myth is simple. It claims that large investors in private equity funds use their bargaining power to negotiate for robust protections in fund agreements that benefit all investors in a fund. Because fund agreements are highly negotiated, so the myth goes, concerns about the substantive quality of their terms must be unwarranted. ${ }^{9}$

This defense has strong surface-level appeal. If fund agreements really are heavily negotiated by large investors, it would create a presumption that the terms in them are not deficient, despite what critics say. Classical contract theory holds that unrestricted freedom of contract between parties that possess equal bargaining power, skill, and knowledge of relevant market conditions enhances individual welfare and promotes an efficient allocation of resources. ${ }^{10}$

1. See infra note 77 and accompanying text.

2. See infra note 54 and accompanying text.

3. See infra notes $76-79$ and accompanying text.

4. See infra notes 87-90 and accompanying text.

5. James C. Spindler, How Private Is Private Equity, and at What Cost?, 76 U. CHI. L. Rev. 311,333 (2009) ("One could view the typical private-equity setup as creating almost an incubator for agency costs, an incredibly hospitable environment for opportunistic managerial behavior.").

6. See The Rise and Rise of Private Equity, MCKInSEY \& COMPANY (Feb. 2018), https://www.mckinsey.com/industries/private-equity-and-principal-investors/our-insights/the-rise-andrise-of-private-equity [https://perma.cc/6XRJ-KQ9J] ("Private markets' assets under management (AUM), which include committed capital, dry powder, and asset appreciation, surpassed $\$ 5$ trillion in 2017, up 8 percent year on year.").

7. Public pension plans are by far the largest investor type in private equity funds, representing $35 \%$ of all investment. See Preqin, Global Private Equity \& Venture CaPITAL RePORT 73 (2018); see also Andrew J. Bowden, Dir., Office of Compliance Inspections \& Examinations, U.S. Sec. \& Exch. Comm'n, Address at the Private Equity International Private Fund Compliance Forum: Spreading Sunshine in Private Equity (May 6, 2014), https://www.sec.gov/news/speech/2014-spch05062014ab.html [https://perma.cc/QK8R-XKV8] (noting that misconduct in the private equity industry "adversely affects the retirement savings of teachers, firemen, police officers, and other workers across the U.S.").

8. See infra note 91 and accompanying text.

9. See infra Part II.

10. See, e.g., RESTATEMENT (SECOND) OF CONTRACTS $\$ 72 \mathrm{cmt}$. b (AM. LAW INST. 1981) ("Bargains are widely believed to be beneficial to the community in the provision of opportunities for 
The benefits of fund agreement negotiations thus would be enjoyed by all investors in private equity funds, not just the large ones.

Closer examination, however, reveals that large investors cannot simply be relied on to play this role. Unlike in a corporate setting, ${ }^{11}$ large investors in private equity funds commonly use their bargaining power to negotiate for individualized benefits outside of fund agreements, where the benefit of the bargain is not shared with other investors in the fund. These individualized benefits, which can include fee discounts and rights to participate in coinvestments alongside the fund (among others), ${ }^{12}$ fundamentally alter large investors' incentives. When individualized benefits are common, they can diminish large investors' incentives to demand strong protections in fund agreements in two ways.

First, individualized benefits can weaken large investors' incentives to negotiate fund agreements. In general, the more that an investor can use its bargaining power to negotiate for individualized benefits before it negotiates for things that will benefit all investors in the fund (like fund agreement protections), it will be a more "efficient" use of that investor's bargaining power. ${ }^{13}$ This does not eliminate the negotiation of fund agreements, but, when individualized benefits are common, it is likely to have a dampening effect on the extent to which fund agreements are negotiated.

Second, individualized benefits can also weaken large investors' incentives to "vote with their feet" by refusing to invest in funds that have suboptimal protections. In the absence of negotiation, the quality of a fund agreement's terms will be shaped by the preferences of the "marginal" investors in that market, ${ }^{14}$ which are the investors that will stop investing when the quality of the fund agreement terms starts to decline. ${ }^{15}$ This Article shows that bargaining power can actually make large investors less sensitive to the

freedom of individual action and exercise of judgment and as a means by which productive energy and product are apportioned in the economy. The enforcement of bargains rests in part on the common belief that enforcement enhances that utility.").

11. One of the core principles of corporate law is that shareholders holding the same class of shares should be treated similarly. See Reinier H. KraAkMAN et AL., THE ANATOMY OF CORPORATE LAW: A COMPARATIVE AND FUNCTIONAL APPROACH 96 (2d ed. 2009) (stating that the equal treatment of shareholders in the same class is a fundamental norm of corporate law); Victor Brudney, Equal Treatment of Shareholders in Corporate Distributions and Reorganizations, 71 CALIF. L. REV. 1072, 1074 (1983) (stating that all shares of common stock are to be treated as "homogeneous claims on enterprise wealth" in a public corporation).

12. See infra Section III.D for a discussion of the various forms that these individualized benefits can take.

13. An "efficient" use of bargaining power in this context is one that achieves the greatest personal benefit possible in return for the investor's bargaining power. See infra Section III.A.2.

14. This assumes a competitive market where buyers have alternative options. See G. Marcus Cole, Rational Consumer Ignorance, 11 J.L. ECON \& POL'Y 413, 414 (2015) (“[N]on-price terms, like price terms, are 'policed' in competitive markets by the marginal consumer for each term.").

15. See id. at 422 ("[T]he marginal consumer, by definition, is the party for whom a particular term means the most. . . The marginal consumer is someone who cares so much about that particular term, that she has educated herself, researched the product terms, and its closest substitutes along the margin of that all-important dimension-whatever it happens to be."). 
quality of fund agreement terms because it enables them to negotiate for individualized benefits that offset the harm caused by weak fund agreement protections. This means that large investors may sometimes be willing to invest in funds that they would otherwise find unacceptable if they lacked bargaining power. ${ }^{16}$ As a result, large investors with bargaining power may not always be the marginal investors - those whose preferences have the greatest influence on the quality of fund terms - in the private equity funds that they invest in. ${ }^{17}$

The incentives described above will apply when large investors are acting rationally to maximize returns for their beneficiaries. But this may not always be the case. The largest investors in private equity funds are public pension plans, whose staff members have sometimes been shown to suffer from agency problems. ${ }^{18}$ These agency problems can dampen their incentive to demand strong protections, even when doing so would be beneficial for plan beneficiaries. ${ }^{19}$

Challenging the private equity negotiation myth is important for a few reasons. Most fundamentally, it shows that the criticisms of fund agreements raised in recent years cannot be dismissed by simply invoking negotiation. At its core, the private equity negotiation myth is a process-based response to substantive criticisms. It argues that because the process by which fund agreement terms are created is sound, substantive scrutiny of those terms is unwarranted and unnecessary. This Article shows that policymakers should not simply take the negotiation myth at face value. Just because there are large investors in the industry that have bargaining power, it cannot automatically be assumed that fund agreements will always have robust protections for all investors in them. ${ }^{20}$

This Article also contributes to broader policy discussions at both the state and federal levels. At the state level, this analysis advances the literature on the controversial practice of waiving fiduciary duties in non-corporate entities like

16. See infra Section III.B.2 for an illustrative example.

17. See infra Section III.B.2.

18. See Josef Lakonishok, Andrei Shleifer \& Robert W. Vishny, The Structure and Performance of the Money Management Industry, in BROOKINGS PAPERS ON ECONOMIC ACTIVITY, MiCROECONOMICS 339 (Clifford Winston ed., 1992) (finding significant underperformance by pension plans attributable to agency problems, including actions taken by pension employees to shift responsibility for poor performance); Paul Gompers \& Josh Lerner, The Use of Covenants: An Empirical Analysis of Venture Partnership Agreements, 39 J.L. \& ECON. 463 (1996) (finding that institutional investor employees show a willingness to allow value to be transferred to fund managers in complex ways that are difficult for outsiders and superiors to detect, but not in ways that can be more easily observed and scrutinized); George Pennacchi \& Mahdi Rastad, Portfolio Allocation for Public Pension Plans, 10 J. PENSION ECON. \& FIN. 221 (2011) (finding that public pension plans tend to allocate assets based on the performance of peer pension funds rather than based on hedging the plan's liabilities due to staff career concerns).

19. See infra Section III.C.

20. To be clear, I am not claiming that a legitimate process-based defense does not exist for private equity fund agreements. For example, if all investors in the private equity market are sufficiently sophisticated to analyze fund agreements and search the market for alternatives, then lack of negotiation may not be problematic at all. This Article focuses on the negotiation-based defense raised by the industry in recent years and does not examine the legitimacy of alternative defenses. 
limited partnerships and limited liability companies. It builds on commentary by Leo Strine, Chief Justice of the Delaware Supreme Court, and Travis Laster, Vice Chancellor of the Delaware Chancery Court, questioning the policy of allowing alternative entity managers to waive their fiduciary duties, and it also fills important gaps in that analysis in the context of private equity funds. ${ }^{21}$

At the federal level, this Article's analysis lends important insights to current policy initiatives aimed at responding to the dramatic rise of private markets in recent years. ${ }^{22}$ The SEC recently launched a comprehensive reexamination of the federal securities laws that regulate investor access to private funds, ${ }^{23}$ with an eye toward opening up more opportunities for retail investors to gain exposure to private investments. ${ }^{24}$ In response to concerns about investor safety, one influential research organization has argued that retail investors could rely on large institutional investors to demand strong protections on their behalf if they were granted access to private equity funds. ${ }^{25}$ This Article shows why policymakers should view any such claims skeptically.

This Article proceeds as follows. Part I discusses conflicts of interest that arise in private equity funds and the various forms of protection against these conflicts commonly used in private equity funds. Part II summarizes some of the most pointed criticisms of private equity fund agreements in recent years and shows how the industry has responded by raising the private equity negotiation myth in its defense. Part III challenges the myth by arguing that

21. See Leo E. Strine, Jr. \& J. Travis Laster, The Siren Song of Unlimited Contractual Freedom, in RESEARCH HANDBOOK ON PARTNERSHIPS, LLCS AND ALTERNATIVE FORMS OF BUSINESS ORGANIZATIONS 11 (Robert W. Hillman \& Mark J. Loewenstein eds., 2015).

22. See infra Section IV.B. The rise of private markets has been attended by a related decline in U.S. public markets. See Maureen Farrell, America's Roster of Public Companies Is Shrinking Before Our Eyes, WALL ST. J. (Jan. 6, 2017), https://www.wsj.com/articles/americas-roster-of-publiccompanies-is-shrinking-before-our-eyes-1483545879 [https://perma.cc/ELA4-YN6A] ("Since the financial crisis, the equity market has become bifurcated, with a private option available to select investors and a public one that is more of a last resort for companies."); Jonathan Macey, Opinion, As IPOs Decline, the Market Is Becoming More Elitist, L.A. TIMES (Jan. 10, 2017) https://www.latimes.com/opinion/op-ed/la-oe-macey-ipo-democracy-20170110-story.html

[https://perma.cc/66K2-4A9D] ("It's not an exaggeration to say that the IPO market is in the beginning of a death spiral as observers assume that any company that resorts to raising money in an IPO must already have been rejected by the more sophisticated investors in the private capital markets.").

23. See SEC, Concept Release on Harmonization of Securities Offering Exemptions (June 18, 2019), https://www.sec.gov/rules/concept/2019/33-10649.pdf [https://perma.cc/N4V3-WEGG].

24. See Davis Polk, Private Equity Regulatory Update 3 (July 31, 2019), https://www.davispolk.com/files/2019-07-31_private_equity_regulatory_update_july_2019.pdf

[https://perma.cc/K8BH-LZ48] ("[T]here are [Concept Release] sections that focus on opening up investments in private companies and private funds to retail investors. One of the major themes of the Concept Release is that the SEC has recognized that retail investors' inability to participate in private opportunities, either directly or through investment funds, may be disadvantaging them economically.").

25. See COMm. on CAPital Mkts. Regulation, EXPANDing OpPORTUNities FOR INVESTORS AND RETIREES: PRIVATE EQUITY 36 (Nov. 2018), https://www.capmktsreg.org/wpcontent/uploads/2018/10/Private-Equity-Report-FINAL-1.pdf [https://perma.cc/4SR9-KVQN] ("Congress could establish or empower the SEC to establish any ... protections for retail investors that they deem necessary. For example, . . . Congress or the SEC could only permit a private equity fund to accept retail investors if the assets managed by the affiliated manager include a material institutional component (e.g., more than 50\%). Such a requirement would enable retail investors to leverage the demands of institutional investors."). 
large investors cannot be counted on to demand strong protections in fund agreements through negotiation or by "voting with their feet." It also provides a concise description of the various forms of individualized benefits that investors can seek to negotiate for in private equity funds. Part IV concludes with a discussion of policy implications.

\section{Conflicts of Interest in Private Equity Funds}

\section{A. Basic Conflicts of Interest}

Private equity managers ${ }^{26}$ invest other people's money for a fee. They raise money by pooling the capital of their various investors into a single vehicle called a fund. Fund investors generally commit different levels of capital to the fund-some commit very large amounts while others commit much smaller amounts. These "pooled" funds are typically organized as limited partnerships ${ }^{27}$ and governed by a limited partnership agreement (an "LPA"), a document that is collectively negotiated between the manager and the fund's investors and sets forth the terms of the fund. Private equity LPAs are long and complicated agreements, typically over 100 pages long. ${ }^{28}$ By and large, the industry is very lightly regulated. ${ }^{29}$

26. To avoid unnecessary complexity, I will use the term "manager" through most of this Article, even in cases where other terms (like "sponsor" or "adviser" or "general partner") may be more technically correct. Any technical distinctions will not be important for purposes of this Article. I will also generally use the term "investor" throughout this Article, even in cases where the term "limited partner" might be more technically correct, for similar reasons.

27. Because funds are usually structured as limited partnerships, the limited partnership architecture applies to these vehicles. Accordingly, investors are passive "limited partners," and the manager acts through a "general partner" that has broad authority to control the fund.

28. See Marco Da Rin \& Ludovic Phalippou, The Importance of Size in Private Equity: Evidence from a Survey of Limited Partners, 31 J. Fin. InTERMEDIATION 64, 69 (2016) ("LPAs are technical and lengthy documents, typically over 100 pages.").

29. See Douglas Cumming \& Sofia Johan, Regulatory Harmonization and the Development of Private Equity Markets, 31 J. BANKING \& FIN. 3218, 3219 (2007) ("The dearth or lack of regulations in private equity to which we refer is related to the fact that investors in private equity funds are institutional investors and high net worth individuals (not the so-called unsophisticated retail investors) and therefore these funds do not receive the same degree of scrutiny as other types of retail based funds, such as mutual funds.”). 


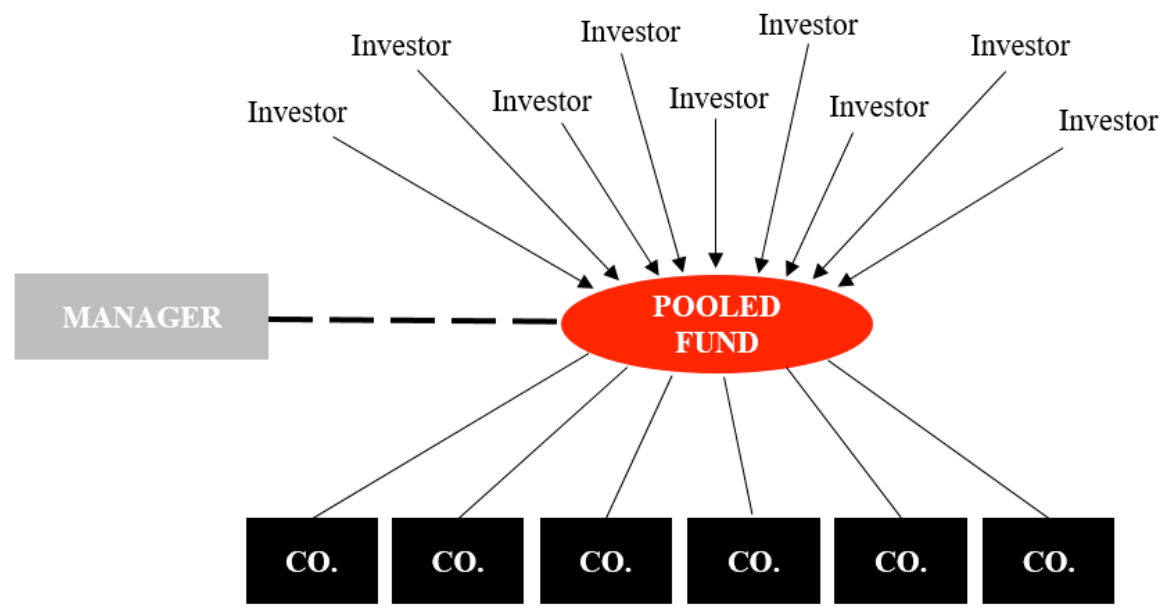

Figure A. Illustrative Private Equity Fund

Once a fund is formed, a manager has an "investment period"-typically three to five years ${ }^{30}$-during which the fund is free to make investments. These investments are known as "portfolio companies," and a manager's objective is to buy companies that are undervalued or that would benefit from changes to strategy or management. During the investment period, investors are contractually obligated to contribute capital to the fund each time the manager makes a "capital call" so the fund can make investments and pay the fund's fees and other expenses. Managers typically have extremely broad discretion to select investments, and investors generally have very few rights to influence the fund's activities. ${ }^{31}$

After a number of years, the manager seeks to sell the fund's portfolio companies or take them public through initial public offerings, hoping to make profits upon the disposition. Each fund has a stipulated end date (typically around ten years after the date of the fund's closing) ${ }^{32}$ by which the manager

30. See Stephanie Breslow \& Phyllis Schwartz, Private Equity Funds: Formation AND OPERATION § 2:4.2 (Carol Benedicto ed., Practising Law Inst. 2015) ("The appropriate length of the commitment period will vary depending on the investment strategy of the fund, with a time period of three to five years being typical for many strategies.").

31. For this reason, traditional private equity funds are commonly called "blind pools" because investors are signing up to invest in them without any knowledge of, or control over, the investments that will be made by the manager. See Spindler, supra note 5, at 328-29 ("While the [LPA] will usually impose strict obligations upon the limited partner to provide capital to the partnership, the limited partner has very little control over what the capital is used for.").

32. See Ronald W. Masulis \& Randall S. Thomas, Does Private Equity Create Wealth? The Effects of Private Equity and Derivatives on Corporate Governance, 76 U. CHI. L. REV. 219, 222 (2009) (noting that private equity funds are typically established for ten-year terms). 
must dispose of any remaining assets and distribute the proceeds to the fund's investors. ${ }^{33}$

Conflicts of interest in private equity funds stem from the separation of ownership and control in the private equity fund structure. ${ }^{34}$ For example, private equity managers may be incentivized to invest less time and effort than they would if they were managing their own money, or they may seek to enrich themselves at the expense of their investors. Manager self-dealing could take the form of secretly charging excessive fees and expenses or of keeping the best investment opportunities for personal investment rather than allocating them to the fund, among any number of others. ${ }^{35}$

\section{B. Protections Against Conflicts}

Legal scholars and financial economists have theorized about the ways in which private equity investors can defend against agency conflicts in the absence of mandatory legal protections. ${ }^{36}$ The combination of contractual protections, paired with a manager's reputational incentives, are generally seen as the most important tools. Each is considered below.

Before committing to invest in a fund, investors have an opportunity to review the LPA governing the terms of the fund. LPAs contain a number of provisions that are designed to protect investors from conflicts with the fund manager. ${ }^{37}$ One way that LPAs seek to limit these conflicts is through the

33. Often, the life of a fund can be extended for successive one- or two-year periods to liquidate and wind up investments.

34. See generally AdOlF A. Berle, JR. \& Gardiner C. MEANS, THE MOdern Corporation AND PRIVATE PROPERTY (1933); Michael C. Jensen \& William H. Meckling, Theory of the Firm: Managerial Behavior, Agency Costs and Ownership Structure, 3 J. FIN. ECON. 305, 308 (1976) (describing the relationship between investor and manager as one "under which one or more persons (the principal(s)) engage another person (the agent) to perform some service on their behalf which involves delegating some decision-making authority to the agent").

35. See infra Section II.A for a discussion of some of the conflicts that have been criticized in private equity funds.

36. See, e.g., Paul Gompers \& Josh Lerner, The Venture Capital Cycle 158 (2d ed. 2004); Vladimir A. Atanasov, Vladimir I. Ivanov \& Kate Litvak, Does Reputation Limit Opportunistic Behavior in the VC Industry? Evidence from Litigation Against VCs, 67 J. Fin. 2215 (2012); Victor Fleischer, The Missing Preferred Return, 31 J. CORP. L. 77, 80 (2005); Lee Harris, A Critical Theory of Private Equity, 35 DEL. J. CORP. L. 259, 285 (2010); Steve Kaplan \& Antoinette Schoar, Private Equity Performance: Returns, Persistence and Capital Flows, 60 J. FIN. 1791, 1791 (2005) (finding that better performing managers are more likely to raise successor funds and larger funds); Kate Litvak, Monte Carlo Simulation of Contractual Provisions: An Application to Default Provisions in Venture Capital Limited Partnership Agreements, 98 CoRNELl L. REV. 1495, 1498 (2013); Kate Litvak, Venture Capital Limited Partnership Agreements: Understanding Compensation Arrangements, 76 U. CHI. L. REV. 161, 162 (2009); Andrew Metrick \& Ayako Yasuda, The Economics of Private Equity Funds, 23 REV. Fin. STUD. 2303 (2010); John Morley, The Separation of Funds and Managers: A Theory of Investment Fund Structure and Regulation, 123 YALE L.J. 1228, $1254-55$ (2014); Larry E. Ribstein, Partnership Governance of Large Firms, 76 U. CHI. L. REV. 289, 298-99 (2009); William A. Sahlman, The Structure and Governance of Venture-Capital Organizations, 27 J. FIN. ECON. 473, 489-516 (1990); Spindler, supra note 5, at 332 .

37. See David T. Robinson \& Berk A. Sensoy, Do Private Equity Fund Managers Earn Their Fees? Compensation, Ownership and Cash Flow Performance, 26 REV. FIn. STUD. 2760, 2760 (2013) 
manager's compensation arrangements. In addition to "management fees," which are calculated as an annual percentage of the investor's total investment in the fund, ${ }^{38}$ private equity managers typically receive a percentage interest in the profits of the fund called a "carried interest,"39 which generally results in them receiving higher compensation as the profitability of the fund increases. Managers are also generally required to invest a certain amount of their own money directly in the fund itself alongside the pooled fund investors. Depending on how the manager's carried interest and commitment to invest in the fund are structured in the LPA, they can shape the manager's incentives in various ways and afford greater or lesser protection to investors.

LPAs also contain various non-economic provisions designed to address agency conflicts. For example, investors are sometimes granted the right to consent to certain transactions when the manager's interest is conflicted, or to dissolve the fund if the manager engages in certain forms of misconduct. ${ }^{40}$ LPAs also sometimes include requirements that the manager's key employees dedicate a certain percentage of their time to working for the fund. ${ }^{41}$ Terms designed to limit risk-taking by the manager - such as restrictions on borrowing and requirements for diversification of investments - can also be included. ${ }^{42}$ Funds also commonly establish "advisory boards" consisting of the fund's largest investors, which are sometimes given limited rights to consult with the manager or consent to certain types of transactions. ${ }^{43}$

In addition to contractual protections, agency conflicts in funds are limited by managers' incentive to maintain a good reputation. Because private equity funds have limited lives ${ }^{44}$ private equity managers must raise funds on a serial basis if they desire to remain in business. Managers commonly start raising a

("In private equity, the agency relationship between fund managers (the general partners, or GPs) and investors (the limited partners, or LPs) is governed by a management contract that is signed at the inception of the fund.").

38. See BRESLOW \& SCHWARTZ, supra note 30, § 2:8.2[B][1] ("The market rate for management fees of private equity funds is approximately $1.5 \%-2 \%$ of the fund's aggregate capital commitments during the fund's investment period.").

39. Historically, the conventional carried interest percentage has been between $15-20 \%$ of the fund's profits over a "hurdle" rate of 5-12\%. See JAMES M. SChELl ET AL., PRIVATE EQUiTy FundS: BUSINESS STRUCTURE AND OPERATIONS $§ 2.03[2]$ (2018) ("Fixed rate preferred returns commonly range from $5 \%$ to $12 \% . ")$.

40. See id. \$11.12[1].

41. See id. § 11.04[6] (“[A] 'key person provision’ generally refers to a contractual provision that grants various rights and remedies to the investors upon the departure or disabling conduct of a specified number of 'key persons.' The 'key persons' are typically defined in the partnership agreement as the Principals or senior managers of the Fund.").

42. See id. $\S 11.07[2][\mathrm{b}]$ ("In the case of most private equity funds, a policy concerning diversification is imposed as a contractual requirement. In many cases, a private equity fund will generally not be allowed to invest more than $20 \%$ to $25 \%$ of its total capital commitments in the securities of any single portfolio company.").

43. See id. § 11.07[8] ("From the Limited Partners' perspective, an Advisory Board represents a mechanism for a limited degree of oversight in areas where the interests of the General Partner may not be fully aligned with those of the Limited Partners.").

44. See Masulis \& Thomas, supra note 32, at 222 (noting that private equity funds are typically established for ten-year terms). 
new fund for a given strategy every three to five years, launching a new fund each time the investment period of a prior fund draws to a close.

If a manager wants to raise funds in the future, it has an incentive to achieve a successful "track record" of investment returns in its current fund because investors want to see evidence of the manager's capabilities before they commit their money. ${ }^{45}$ A manager's history of past performance is typically provided to investors in the marketing materials that they distribute to prospective investors when they raise a fund.

Managers are also subject to fiduciary duties under state limited partnership law $^{46}$ and under the federal Investment Advisers Act of 1940 (the "Advisers Act"). ${ }^{47}$ However, in Delaware, the state in which most private equity fund limited partnerships are formed,${ }^{48}$ fiduciary duties can be modified, or even waived entirely, by an LPA's terms, ${ }^{49}$ and under the Advisers Act, fiduciary duties can largely be satisfied by disclosure of conflicts and other risks. ${ }^{50}$ The world of private equity funds is thus highly contractual, and neither

45. See Ronald J. Gilson, Engineering a Venture Capital Market: Lessons from the American Experience, 55 STAN. L. REV. 1067, 1089-90 (2003) (“A [manager's] track record . . . is the [manager's] principal tool for persuading investors to invest in successor funds."); see also PREQIN, KEY DUE DILIGENCE CONSIDERATIONS FOR PRIVATE EQUITY INVESTORS (2014), https://docs.preqin.com/reports/Preqin-Special-Report-Due-Diligence-Private-Equity-Investors-Jul-

14.pdf [https://perma.cc/RFA6-ZRXQ] (reporting the results of a survey showing that both placement agents and investment consultants believe the track record of the investment team is the most important indicator that a fund will outperform peer funds); Curtis J. Milhaupt, The Market for Innovation in the United States and Japan: Venture Capital and the Comparative Corporate Governance Debate, $91 \mathrm{Nw}$. U. L. REV. 865, 886 (1997) ("[T] he short life of limited partnerships virtually guarantees that the venture capitalists will undergo a 'periodic performance review' at the hands of their current investors who are, inevitably, potential future investors as well.").

46. These include a duty of loyalty, which, among other things, requires that the general partner refrain from dealing with the partnership on behalf of a party that has an adverse interest and from competing with the partnership, and a duty of care. See, e.g., DEL. CODE ANN. tit. 6, § 15-404(b), (c) (2018); REVISED UNIF. LTD. P'SHIP ACT § 403(b) (1976); UNIF. LTD. P'SHIP ACT § 408 (1916).

47. See SEC v. Capital Gains Research Bureau, 375 U.S. 180, 196 (1963) ("The Investment Advisers Act of 1940 thus reflects a congressional recognition 'of the delicate fiduciary nature of an investment advisory relationship,' as well as a congressional intent to eliminate, or at least to expose, all conflicts of interest which might incline an investment adviser . . . to render advice which was not disinterested.").

48. See Private Equity (Fund Formation), GetTing the Deal Through (Mar. 2019), https://gettingthedealthrough.com/area/28/jurisdiction/23/private-equity-fund-formation-2019-unitedstates [https://perma.cc/33XJ-VHSR] ("In the United States, private equity funds are typically formed as limited partnerships in the State of Delaware, pursuant to the Delaware Revised Uniform Limited Partnership Act (DRULPA)."); Robert Schwartz, Delaware as a Location for Private Funds: The Why and the What, WORLD SEC. L. REP. (BNA) (Aug. 10, 2012).

49. See, e.g., DEL. CoDE ANN. tit. 6, § 17-1101(d) (2018) (“To the extent that, at law or in equity, a partner or other person has duties (including fiduciary duties) to a limited partnership or to another partner or to another person that is a party to or is otherwise bound by a partnership agreement, the partner's or other person's duties may be expanded or restricted or eliminated by provisions in the partnership agreement; provided that the partnership agreement may not eliminate the implied contractual covenant of good faith and fair dealing."). Note, however, that the more limited implied contractual covenant of good faith and fair dealing cannot be waived under Section 18-1101(c) of the Delaware Limited Liability Company Act. See Del. CoDE ANN. tit. 6, § 18-1101(c) (2018).

50. See Capital Gains Research Bureau, 375 U.S. at 196 (citing United States v. Miss. Valley Generating Co., 364 U.S. 520 (1961)) (holding that investors must "be permitted to evaluate overlapping motivations, through appropriate disclosure, in deciding whether an adviser is serving 'two masters' or 
state nor federal law provide investors with meaningful back-up protection if the combination of LPA-based protections and reputation-based protections is deficient.

\section{The Private Equity Negotiation Myth}

LPAs are held up as one of the primary sources of investor protection against managerial exploitation in private equity funds, but they have been criticized by many in recent years. One response to this criticism has been for the industry to invoke what I call the private equity negotiation myth as a defense. ${ }^{51}$ Because LPAs are heavily negotiated by large investors, so the argument goes, there is no basis for outside observers to criticize the substance of these agreements.

\section{A. Critiques of Private Equity LPAs}

\section{Scholarly Critiques}

Scholars have accused LPAs of being deficient in a number of ways over the years. ${ }^{52}$ One line of criticism argues that the compensation arrangements set forth in LPAs, which are supposed to align managers' interests with their investors' interests, ${ }^{53}$ actually create serious conflicts of interest. Scholars have criticized carried interest compensation for encouraging excessive risk-taking by managers in their investment decisions, ${ }^{54}$ creating a moral hazard problem because managers enjoy the upside of strong performance without downside

only one, 'especially ... if one of the masters happens to be economic self-interest'"); Andrew Ceresney, Dir., Div. of Enforcement, U.S. Sec. \& Exch. Comm'n, Securities Enforcement Forum West 2016 Keynote Address: Private Equity Enforcement (Mar. 12, 2016), https://www.sec.gov/news/speech/private-equity-enforcement.html [https://perma.cc/47JT-FLA7] (indicating that managers must "disclose sufficiently specific facts such that the client is able to understand the [manager's] conflicts of interest and business practices, and can give informed consent to such conflicts or practices"). As a result, if a manager has disclosed certain risks and investors have not negotiated for contractual protections against those risks, the investors will be exposed to those risks without any protection from federal fiduciary duties.

51. See infra note 91 and accompanying text.

52. See, e.g., Robinson \& Sensoy, supra note 37, at 2761 ("[T] contract allows GPs to earn excessive compensation and does too little to discipline GPs or to provide them with incentives to maximize LP returns.").

53. See supra note 39 and accompanying text.

54. See, e.g., Gilson, supra note 45, at 1089 ("While aligning the interests of the GP and the investors, the intensity of the GP's compensation incentive in turn creates a different agency cost. The GP's carried interest has option-like characteristics, which may cause it to prefer investments of greater risk than the investors. This is especially true with respect to the fund's later investments if the early ones have done poorly. In that circumstance, the GP actually may be best served by making negative net present value investments if the investments are sufficiently risky."); Harris, supra note 36, at 285 ("One of the problems of incentive compensation provisions ... is that the compensation structure may encourage a manager to make overly risky investment decisions ...."). 
risk. ${ }^{55}$ Carried interest has also been criticized for distorting managers' decision-making in other ways, including giving them an incentive to shorten their investment horizons and time cash flows in ways that will increase incentive fees ${ }^{56}$ Separately, scholars have also argued that the carried interest formulations in LPAs are unnecessarily and overly complex, making it harder for investors to understand exactly how much they are obligated to pay. ${ }^{57}$

One of the most controversial critiques of LPAs in recent years has to do with portfolio company fees charged by private equity fund managers. These fees are not paid directly by investors. Instead, they are paid by the portfolio companies owned by the fund, as illustrated in Figure B. These fees have often taken the form of "monitoring" fees or "consulting" fees-the idea is that the portfolio companies pay managers for "services" that the managers provide to the portfolio companies. However, because portfolio companies are ultimately controlled by a fund's manager (because the manager controls the fund that owns the portfolio company), the timing and amount of these payments have historically been controlled by the manager. Skeptical of the value actually provided by these services, some scholars have called these fees "money for doing nothing." 58

55. See, e.g., William Magnuson, The Public Cost of Private Equity, 102 MinN. L. REv. 1847, 1872 (2018) ("The carried interest element of private equity compensation creates a moral hazard problem in the private equity industry that in many ways mirrors the critiques levied against the banking industry after the financial crisis of 2008-2009.”).

56. See Ludovic Phalippou, Beware of Venturing into Private Equity, 23 J. ECON. PERSPS. 147, 162 (2009) ("To isolate further potential conflicts between the managers of private equity buyout funds and their outside investors, I discuss a few features of buyout contracts that exacerbate conflicts of interest, rather than mitigate them. First, managers have an incentive to time cash flows in a way that will increase incentive fees. Second, certain contracts provide steep incentives for shortening investment horizons. Third, transaction fees may distort choices of buyout firms in terms of leverage, size of investment, and number of changes in capital structure.").

57. See, e.g., Peter Morris \& Ludovic Phalippou, A New Approach to Regulating Private Equity, 12 J. CORP. L. STUD. 59 (2012) (positing that complexity in an LPA's carried interest provision can benefit managers by making it harder for investors to understand it).

58. Eileen Appelbaum \& Rosemary Batt, Ctr. For ECON. \& Policy Research, Fees, FEES AND MORE FEES: HOW PRIVATE EQUITY ABUSES ITS LIMITED PARTNERS AND U.S. TAXPAYERS 12 (May 2016), http://cepr.net/images/stories/reports/private-equity-fees-2016-05.pdf [https://perma.cc/HSE2-2J4Z]. 


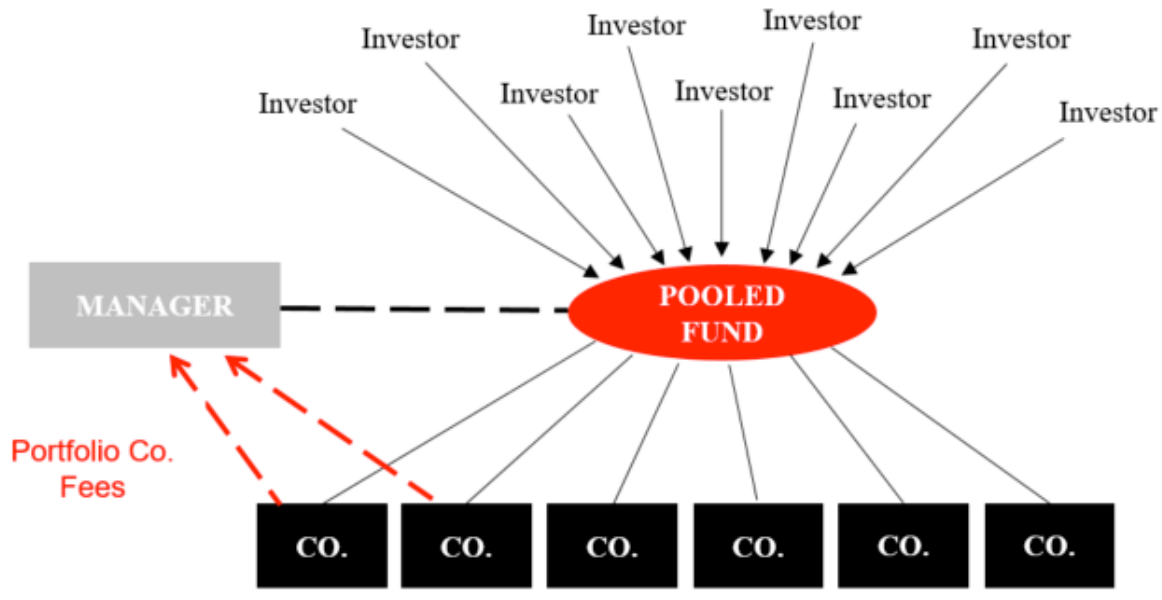

Figure B. Portfolio Company Fees

The payment of portfolio company fees has historically been authorized by language in LPAs that permits managers to charge them in a general sense but otherwise provides little specificity about the timing and nature of these fees ${ }^{59}$ Scholars have raised concerns that LPAs thus effectively gave managers freedom to charge an unspecified amount in fees in the future without obtaining investors' specific consent to those fees. ${ }^{60}$ While many LPAs stipulate that all or a portion of these portfolio company fees will eventually be reimbursed to investors or offset fees that would otherwise be paid by investors,${ }^{61}$ critics have argued that vague language in LPAs can lead to those rebates and offsets never being realized. ${ }^{62}$

59. See id. at 1 ("[V]ague and misleading wording allows PE firms to take advantage of their asymmetric position of power vis-à-vis investors and the lack of transparency in their activities.”).

60. See, e.g., Ludovic Phalippou, Christian Rauch \& Marc Umber, Private Equity Portfolio Company Fees, 129 J. FIN. ECON. 559, 560 (2018) ("[Investors] do not agree on all fees ex ante and leave ex post discretion to [managers]. . . . The amount of fees charged to portfolio companies is not specified in the LPA; they are contracted upon in the Management Services Agreements which are signed by the [manager] and representatives of the company at the time of the transaction.").

61. This approach has become quite common in recent years. See Graeme Kerr, LPs Demand More Granularity, PRIV. FUNDS MGMT., Nov. 2018, https://www.pepperlaw.com/resource/33536/14G0 [https://perma.cc/FYZ8-JJBA] (showing that $47 \%$ of survey respondents offset $100 \%$ of portfolio company monitoring fees against management fees, with $35 \%$ of survey respondents offsetting between $80-100 \%$ of portfolio company monitoring fees against management fees).

62. See APPELBAUM \& BATT, supra note 58, at 10-11 ("Many current Limited Partnership Agreements stipulate that a portion of the transaction and monitoring fees charged to portfolio companies will be rebated to the PE fund's limited partners. But vague and confusing wording in the LPAs has meant that too often . . . these investors have not received the fee income that is owed them; instead, it has been pocketed by the PE firm. Even when LPs are reimbursed out of these fees, the LP can only receive the amount it has paid in management fees. Monitoring fees in excess of those payments are retained solely by the PE firm."). 
Scholars have also criticized LPAs for failing to require that managers provide sufficiently robust information disclosures to their investors. ${ }^{63}$ Compared to shareholders in publicly traded companies, private equity funds have been accused of giving investors only "barebones" information about the fund, and of subjecting investors' information rights to numerous caveats and conditions that benefit managers and keep investors in the dark. ${ }^{64}$ Weak LPAs have thus, according to critics, led to private equity fund managers being among the least transparent actors in the financial marketplace. ${ }^{65}$

When LPAs do not require robust disclosure, it can have compounding effects. ${ }^{66}$ Scholars have argued that weak disclosure diminishes the effectiveness of reputation ${ }^{67}$ as a source of protection against exploitation. ${ }^{68} \mathrm{In}$ order for investors to assess a manager's reputation, they need information about the manager's history and past performance in prior funds. However, if information about a manager's bad acts is never disclosed, the manager cannot be held accountable for those acts. The effectiveness of reputation will be particularly diminished if, as some scholars have argued, weak disclosure obligations enable managers to overstate the performance of their current and prior funds. ${ }^{69}$

The critiques described above, if valid, are exacerbated by the fact that LPAs have long granted weak control rights and exit rights to private equity fund investors. Accordingly, if incentive compensation and reputation really do provide insufficient protection, investors will have limited options for taking matters into their own hands. Some scholars have advocated for stronger control rights. ${ }^{70}$

63. See id. at 7 ("The reporting requirements for private equity [managers] under Dodd Frank are modest compared with what publicly traded companies, mutual funds, and other investment funds must disclose to the SEC."); Spindler, supra note 5, at 325-28 ("[O]nce the investment decision has been made, limited partners are largely in the dark. . . [T] [The information that limited partners receive is somewhat useful in terms of keeping in check gross malfeasance by the general partners but not useful in terms of knowing what their investments are likely to be worth at any point in time or whether the general partners are doing a good job.").

64. See Magnuson, supra note 55, at 1882 ("[E]ven the limited information disclosures that private equity investors are entitled to come saddled with myriad caveats and carve outs.").

65. See APPELBAUM \& BATT, supra note 58, at 6 ("Private equity is among the least transparent financial actors in the economy.").

66. For example, it could mean that investors may never find out, even after the fact, how much a manager was paid in the form of portfolio company fees.

67. See supra note 45 and accompanying text.

68. See, e.g., Magnuson, supra note 55, at 1900 (“ $[\mathrm{R}]$ eputation can only constrain a party's behavior if the party believes that others will receive information about the party's past behavior and base their decision making on that past behavior. In other words, reputation is only as good as the information that underlies it."); Spindler, supra note 5, at 332 ("There is a tendency to overstate the salutary effect of reputation; from a theoretical perspective, the gradual learning that takes place through reputation is inefficient compared to more immediate revelation through greater transparency.").

69. See Magnuson, supra note 55, at 1900-01 ("In this atmosphere of extreme confidentiality, it is unsurprising that a number of studies have found that private equity firm disclosures systematically tend to overstate fund performance.").

70. See, e.g., Magnuson, supra note 55, at 1905 ("[P]rivate equity structures could be reformed to grant limited-partner investors greater governance rights, including voting, transfer, and 
This leads to the last scholarly criticism of private equity fund LPAs that I will summarize here - the elimination of fiduciary duties under state limited partnership law. ${ }^{71}$ If all of the criticism described above applies to a fund and investors cannot rely on the LPA or the manager's reputation for meaningful protection, then their protection of last resort would be the fiduciary duties that managers owe to their investors. Because funds are typically formed as limited partnerships, managers act as general partners of their funds, and are therefore subject to default fiduciary duties under state limited partnership law. ${ }^{72}$ However, as noted above, private equity fund LPAs have long included provisions that explicitly modify, or even eliminate, these fiduciary duties altogether. ${ }^{73}$ Many scholars strongly oppose this highly contractarian approach to fiduciary duties and argue that fiduciary duties are necessary in light of other weaknesses in the private equity fund governance model. ${ }^{74}$

The above criticism does not reflect the full universe of critical academic commentary on private equity fund LPAs, but it gives the reader a sense of some of the most important and frequently cited issues in this area.

\section{Journalistic Critiques}

The news media has also raised strong criticisms of private equity LPAs. Journalists have taken private equity LPAs to task for, among other things, failing to protect against managers engaging in conflicted investment

information rights. Investors would not necessarily need broad governance rights in all of these areas in order to ensure that they are protected from misbehavior or shirking by private equity firms. Instead, greater governance rights in one area might obviate the need for greater governance rights in another."); Spindler, supra note 5, at 314 (" $[\mathrm{O}]$ ne need not take a Bebchukian view of firm agency costs to believe that something more than zero shareholder empowerment is optimal. Some degree of privately negotiated disclosure and control would seem intuitively best."). From a practical perspective, stronger exit rights would be difficult for managers to grant given the long-term holdings of private equity funds.

71. As previously noted, managers also have fiduciary duties pursuant to the Advisers Act. A manager's fiduciary duties under the Advisers Act cannot be waived entirely by contract, but they can be satisfied when the manager simply discloses the existence of the relevant conflicts of interest and risks. See supra note 50 and accompanying text.

72. See, e.g., Paige Cap. Mgmt., LLC v. Lerner Master Fund, LLC, 2011 WL 3505355, at *31 (Del. Ch. Aug. 8, 2011) (holding that "[a]s a matter of default law, [the] General Partner clearly owes fiduciary duties to the limited partners" unless the limited partnership agreement waives such duties).

73. See supra note 49 and accompanying text.

74. See, e.g., APPELBAUM \& BATT, supra note 58, at 16 (“Analyses of Limited Partnership Agreements (LPAs) have also uncovered clauses that specifically allow private equity firms to waive their fiduciary responsibility towards their limited partners-leading to serious conflicts of interest and negative spillover effects for the beneficiaries of pension funds that invest in private equity."); Magnuson, supra note 55, at 1877 ("The inability of private equity investors to participate in governance decisions might be less worrisome if they were protected by strong fiduciary duties. . . . But many limited partnership agreements require investors to waive any fiduciary duties that the private equity firm might otherwise have, thus depriving private equity investors of this judicial check on misbehavior.”). But see Larry E. Ribstein, Fiduciary Duties and Limited Partnership Agreements, 37 SuFFOLK U. L. REV. 927, 930-31 (2004) (arguing against the restriction of fiduciary duty waivers in limited partnerships). 
activities ${ }^{75}$ allowing managers to engage in practices that overstate their returns and enable them to receive inflated incentive compensation, ${ }^{76}$ and failing to provide adequate disclosure of portfolio company fees and other fees. ${ }^{77}$

One particularly controversial practice drawing media scrutiny in recent years has been the custom of requiring investors to sign non-disclosure provisions prohibiting them from sharing LPAs with any third parties. ${ }^{78}$ Commentators have argued that these provisions are included by managers primarily to prevent the public from evaluating LPAs and exposing the unfair provisions in them, ${ }^{79}$ and to make it difficult for investors to benchmark and compare LPAs against each other. Concerns in this area even led one commentator to create a publicly available collection of "leaked" private equity fund LPAs, including LPAs from many of the largest private equity managers

75. See, e.g., Anupreeta Das \& Juliet Chung, Wall Street's New Problem: When Fund Titans Invest on the Side, WALL ST. J. (Apr. 26, 2017), https://www.wsj.com/articles/wall-streets-newproblem-when-fund-titans-invest-on-the-side-1493218214 [https://perma.cc/MQ66-CAMM] ("Wall Street billionaires, their fortunes built by investing other people's money, increasingly are putting some of their own in sideline investment ventures, while continuing to operate their hedge funds or privateequity funds for clients. The side businesses . . . are a growing concern to the pension funds, university endowments and other institutional investors that make up the clientele of hedge funds and privateequity funds.").

76. See, e.g., Chris Flood, Private Equity's Dirty Finance Secret, Fin. TimES (July 27, 2017), https://www.ft.com/content/48d107b2-5fed-11e7-91a7-502f7ee26895 [https://perma.cc/T7GX-QHZ6] ("Money promised by investors is increasingly being used by private equity managers as security for bank loans that are then used to pay for deals in place of a client's capital. This little-discussed technique, known as subscription-line financing, helps private equity managers earn performance fees because one of their funds' key assessment metrics, the internal rate of return, is based on the date an investor's cash is put to work.").

77. See, e.g., Gretchen Morgenson, Challenging Private Equity Fees Tucked in Footnotes, N.Y. TIMES (Oct. 17, 2015), https://www.nytimes.com/2015/10/18/business/challenging-private-equityfees-tucked-in-footnotes.html [https://perma.cc/9X2V-3XNB] ("How much do private equity investors pay to the firms overseeing their portfolios? You might think such a question would be a no-brainer. But in the supersecret world of private equity, it is anything but."); Gretchen Morgenson, Private Equity Funds Balk at Disclosure, and Public Risk Grows, N.Y. TIMES (July 1, 2016), https://www.nytimes.com/2016/07/03/business/private-equity-funds-balk-at-disclosure-and-public-riskgrows.html [https://perma.cc/87HL-CLJM]; Dan Primack, Private Equity's New Fee Trick, ForTuNE (July 1, 2013), https://fortune.com/2013/07/01/private-equitys-new-fee-trick [https://perma.cc/27CS6V9P] ("Most limited partnership agreements allow for additional fees to be charged if the fund is required to hire outside help, such as in the case of a serious legal issue. But . . some general partners are hiring others for tasks that should reasonably be expected to fall under the management fee, in order to juice the bottom line.").

78. See, e.g., Madison Marriage \& Chris Newlands, Pension Funds Forced to Sign NonDisclosure Agreements, FIN. TIMES (Oct. 26, 2014), https://www.ft.com/content/94524a60-5b96-11e481ac-00144feab7de [https://perma.cc/7F39-SFHD] ("Anger has erupted over the practice of asset managers coercing pension funds into signing non-disclosure agreements.”); Gretchen Morgenson, Behind Private Equity's Curtain, N.Y. TIMES (Oct. 18, 2014), https://www.nytimes.com/2014/10/19/business/retirement/behind-private-equitys-curtain.html [https://perma.cc/9TTN-GM79] ("[I]n exchange for what they hope will be hefty returns, many pension funds have signed onto a kind of omerta, or code of silence, about the terms of the funds' investments.").

79. See, e.g., Marriage \& Newlands, supra note 78 ("Critics believe the non-disclosure agreements allow fund managers to overcharge some of their pension clients significantly."); Gretchen Morgenson, The Deal's Done. But Not the Fees, N.Y. Times (May 25, 2014), https://www.nytimes.com/2014/05/25/business/the-deals-done-but-not-the-fees.html

[https://perma.cc/4WPN-MT7E] (quoting SEC official Andrew Bowden as saying in an exclusive interview that "in some instances, investors' pockets are being picked"). 
in the industry. ${ }^{80}$ These criticisms of LPAs are part of a long list of journalistic critiques brought against the private equity industry, relating to various controversial practices in the industry. ${ }^{81}$

\section{The SEC's Critique}

The scholarly and journalistic criticism described above has helped to draw attention to the controversial elements of private equity fund LPAs. But the most impactful critique - the one that has done the most to draw attention to concerns about LPAs - came from the SEC. In the years following the financial crisis, the SEC launched an industry-wide "sweep" of the private equity industry. The goal was for the SEC to establish a presence within the private equity industry ${ }^{82}$ following the enactment of the Dodd-Frank Act, which gave the SEC authority to perform examinations on a much wider universe of fund managers. ${ }^{83}$ Because private equity LPAs and other fund documentation are almost never publicly filed, the SEC's newly expanded authority gave it an opportunity to become more familiar with the unique issues surrounding the private equity business model.

Following this initiative, the SEC publicly announced strongly worded criticisms of what examiners found in the LPAs they examined ${ }^{84}$ Specifically,

80. Private Equity Limited Partnership Agreements, NAKED CAPITALISM, https://nakedcapitalism.net/documents.html [https://perma.cc/PC42-HXVR] (last visited Sept. 12, 2019).

81. See, e.g., Pat Garofalo, The Real Scandal in Private Equity? It's the Taxes, THE ATLANTIC (Jan. 17, 2012), https://www.theatlantic.com/business/archive/2012/01/the-real-scandal-in-privateequity-its-the-taxes/251463 [https://perma.cc/25LY-CFE6] (“[T]here's no value added by letting private equity managers treat the paycheck they receive as capital gains: that particular tax loophole just lets very wealthy money managers avoid paying the top tax rate, for no real reason."); Josh Kosman, Why Private Equity Firms Like Bain Really Are the Worst of Capitalism, ROLLING STONE (May 23, 2012), https://www.rollingstone.com/politics/politics-news/why-private-equity-firms-like-bain-really-are-theworst-of-capitalism-241519 [https://perma.cc/8H6M-3XFE] (describing private equity as "a predatory system created and perpetuated by Wall Street solely to pump its own profits"); Steven Pearlstein, The \$786 Million Question: Does Steve Schwarzman-or Anyone-Deserve to Make That Much?, WASH. POST (Jan. 4, 2019), https://www.washingtonpost.com/business/the-786-million-question-does-steveschwarzman--or-anyone--deserve-to-make-that-much/2019/01/04/ea9f9e9c-0df1-11e9-84fc-

d58c33d6c8c7_story.html [https://perma.cc/JY8F-LXXJ] ("[I]f we, as a society, decide that we find the current distribution of income unacceptable-if it offends our moral intuitions that a single financier earns as much in a year as 15,000 elementary school teachers-then it violates no great moral or economic principle to alter that distribution."); James Surowiecki, Private Inequity, NEW YORKER (Jan. 22 , 2012), https://www.newyorker.com/magazine/2012/01/30/private-inequity [https://perma.cc/9Z84KMUC] (describing the wealth created by private equity as derived "not from management or investing skills but, rather, from the way the U.S. tax system works").

82. See Bowden, supra note 7 (stating that the exam initiative was designed to "establish a presence with the private equity industry and to better assess the issues and risks presented by its unique business model").

83. See Dodd-Frank Wall Street Reform and Consumer Protection Act, Pub. L. No. 111-203, tit. IV, 124 Stat. 1376, 1570 (2010) (eliminating the "private adviser" exemption to registration requirements under the Investment Advisers Act of 1940, which had the effect of requiring all but a small minority of private fund managers to register with the SEC and become subject to the SEC's examination authority).

84. In this Article, I focus on the SEC's claim that private equity fund LPAs are deficient. To be sure, the SEC's remarks also condemned a number of activities that clearly breached LPA terms. In 
the SEC raised the issue of portfolio company fees, noting that broad language in LPAs enabled managers to charge fees and expenses at the portfolio company level that were "not reasonably contemplated by investors." ${ }^{85}$ This helped create an environment where, according to the SEC, "violations of law or material weaknesses in controls" related to fees and expenses were observed in more than half of the funds that were examined.$^{86}$ The SEC also indicated other areas where lack of clarity in the LPA gave managers too much discretion in their interactions with investors, including with respect to asset valuation, fund investment strategies, and protocols for mitigating conflicts of interest. ${ }^{87}$

The SEC also criticized the light disclosure requirements set forth in LPAs. SEC examiners found that LPAs did not provide investors with sufficient information rights to be able to monitor their investments adequately, and that they had broad, imprecise language, which enabled managers to be opaque in areas where investors would benefit from transparency. ${ }^{88}$ This was, from the SEC's perspective, the most important finding of the examination initiative, reinforcing the view of academics that poor disclosure has compounding effects that weaken other forms of investor protection in private equity funds. ${ }^{89}$

All in all, the SEC's comments were a sweeping rebuke of common practices throughout the private equity industry, and they pointedly questioned the adequacy of the LPA as a source of investor protection.

\section{B. The Industry's Negotiation-Based Defense}

In response to the various critiques levied against LPAs, the private equity industry ${ }^{90}$ has frequently defended itself by arguing that these agreements are

those cases, the problem had to do with the manager's conduct, not with shortcomings in the LPAs that permitted managers to engage in harmful conduct. This Article is interested in the deficient LPAs.

85. Bowden, supra note 7 ("Many limited partnership agreements are broad in their characterization of the types of fees and expenses that can be charged to portfolio companies (as opposed to being borne by the adviser). This has created an enormous grey area, allowing advisers to charge fees and pass along expenses that are not reasonably contemplated by investors.").

86. Id. ("When we have examined how fees and expenses are handled by advisers to private equity funds, we have identified what we believe are violations of law or material weaknesses in controls over $50 \%$ of the time.").

87. Id. ("We've also seen limited partnership agreements lacking clearly defined valuation procedures, investment strategies, and protocols for mitigating certain conflicts of interest, including investment and co-investment allocation.").

88. Id. (" $[\mathrm{M}]$ ost importantly, we see that most limited partnership agreements do not provide limited partners with sufficient information rights to be able to adequately monitor not only their investments, but also the operations of their manager. Of course, many managers voluntarily provide important information and disclosures to their investors, but we find that broad, imprecise language in limited partnership agreements often leads to opaqueness when transparency is most needed.").

89. See supra notes 68-69 and accompanying text.

90. References to the "private equity industry" in this Article refer primarily to private equity industry trade groups, including the American Investment Council (formerly known as the Private Equity Growth Capital Council), a national trade association, and the Association for Corporate Growth, a trade association focused on middle-market private equity. See AM. INV. CounCIL, 
highly negotiated documents. ${ }^{91}$ This defense, which I call the "private equity negotiation myth," assumes that large investors can be relied on to negotiate for

https://www.investmentcouncil.org [https://perma.cc/MZ37-26TU]; Ass'N CORP. GROWTH GLOBAL, https://www.acg.org [https://perma.cc/YZ7E-KSW9].

91. See, e.g., Am. Inv. Council, Comment Letter on Proposed Commission Interpretation Regarding Standard of Conduct for Investment Advisers (Feb. 25, 2019), https://www.sec.gov/comments/s7-09-18/s70918-4970860-182100.pdf [https://perma.cc/UQJ9-CUZC] ("[T] $]$ he terms of the LPA are determined after a robust negotiation process that results in the private equity fund sponsor and the fund's limited partners agreeing on the terms of an investment fund in advance of their admission to the fund."); Am. Inv. Council, Comment Letter on Proposed Rule for Adviser Business Continuity and Transition Plans (Sept. 6, 2016), https://www.sec.gov/rules/proposed/2016/ia-4439.pdf [https://perma.cc/37D5-65FM] (“[T]he limited partnership agreements (or other documents) governing fund operations contain specific, negotiated provisions concerning changes in management and ownership and the liquidation of the fund, which we believe accurately reflect what investors expect to happen in times of stress or transition."); Ass'N FOR CORP. Growth, Private Equity Regulatory \& COMPliance Principles 26 (2017), https://www.acg.org/sites/files/ACGPERT_PERCPrinciples.pdf [https://perma.cc/C327-2WV6] (“Terms relating to disclosures and reporting in fund LPAs and side letters are highly negotiated, and reflect the mutually-agreed upon terms between the Manager and the Limited Partners. . . . Firms enter into a highly-negotiated Limited Partnership Agreement ('LPA') with their investors, which may describe the valuation process to be used for that particular Fund."); ASS'N FOR CORP. GROWTH, SEC TASK FORCE SURVEY (2014) ("The allocation of fees and expenses between the general partner of a fund and the limited partners is highly negotiated and memorialized in a formal limited partnership agreement, or LPA.”); Jason Mulvihill, Standardization in PE: Needed Trend or Impractical Solution in Search of a Problem?, in AM. InV. COUNCIL, STATE OF THE InDUSTRY 9, 9 (2017) ("Calls for greater standardization of private equity documents frequently derive from a misunderstanding about the inherent transparency and long-standing success of funds vis-à-vis their investors. As a general proposition, bespoke partnership agreements reflect extensive negotiations between fund sponsors and their sophisticated investors and have served investors and managers well.”); Stephen Beale, Firms Paid Millions to Manage RI Pension Money They Didn't Have, GoLoCal Providence News (July 9, 2015), https://www.golocalprov.com/news/firms-paid-millions-to-manage-ri-pension-money-they-didnt-have [https://perma.cc/R7L4-KMCN] (quoting James Maloney, spokesman for the Private Equity Growth Capital Council, as saying, "[Limited partners,] such as pension funds, incentivize private equity managers to locate the best returns for them. ... All of this is negotiated and explicitly agreed upon in the limited partner agreement"); Chris Flood, SEC Issues Fresh Warning to Private Equity, FIN. TIMES (May 31, 2015), https://www.ft.com/content/f47fc044-0540-11e5-8612-00144feabdc0 [https://perma.cc/H95V-P5GM] ("Steve Judge, chief executive of the Private Equity Growth Capital Council, a trade body, said agreements between private equity managers and institutional investors were 'the result of highly negotiated terms between sophisticated parties."'); Steve Judge, Confidentiality of Limited Partnership Agreements Is Paramount, PE HUB NETWORK (Nov. 3, 2014), https://www.pehub.com/2014/11/confidentiality-of-limited-partnership-agreements-is-paramount [https://perma.cc/TA2X-86YP] ("LPAs are highly negotiated agreements between sophisticated parties and, in the case of public pensions, are entered into by individuals who have a fiduciary duty to act in the best interests of beneficiaries. So it goes beyond reason to believe that they would enter into any agreement that would violate that duty."); Steve Judge, Private Equity and Pensions: A Strong Partnership, PE HUB NETwORK (June 30, 2015), https://www.pehub.com/2015/06/private-equity-andpensions-a-strong-partnership/ [https://perma.cc/K22Z-WAR7] ("[Pension plans] understand very well the investments they are making: They receive extensive disclosure, conduct due diligence, heavily negotiate essentially every aspect of a fund's terms before investing, and pension funds take very seriously their responsibilities to the pensioners they represent."); Morgenson, supra note 79 ("Asked about the SEC's criticisms, Steve Judge, chief executive of the Private Equity Growth Capital Council, the industry's lobbying group, said in a statement: 'Every private equity fund agreement is negotiated by professional investment managers on both sides, creating an alignment of interests that consistently delivers the best returns - net of fees-of any asset class over the long-term.'”); Greg Roumeliotis \& Karen Freifeld, Analysis, New York AG's Private Equity Probe May Have Little Bite, REUTERS (Sept. 7, 2012), https://www.reuters.com/article/us-private-equity-tax-idUSBRE88606E20120907 [https://perma.cc/BP97-QB7Y] (“"Management fee waivers are legal, widely recognized, and often part of negotiated agreements between the alternative investment community and investors, including pension funds and endowments,' said Steve Judge, president of Private Equity Growth Capital Council, 
protections that will benefit all investors in a fund. This is a process-based response to the substantive criticisms that have been brought against private equity fund LPAs. Rather than seek to establish that the terms of LPAs themselves are substantively fair, by invoking the private equity negotiation myth, private equity industry representatives have argued that the process by which the terms were generated is fair. In other words, the industry has used a process-based argument to tell critics that there is "nothing to see" in private equity fund LPAs.

While negotiation is not the only process by which fair terms can be created in a contract, ${ }^{92}$ evidence of robust negotiation between knowledgeable and properly incentivized parties would certainly create a strong presumption that neither party is taking advantage of the other. Classical contract theory holds that unrestricted freedom of contract $^{93}$ between parties with equal bargaining power, skill, and knowledge of relevant market conditions maximizes individual welfare and promotes the most efficient allocation of resources in the marketplace. ${ }^{94}$

If private equity fund LPA terms have always been the product of a fair process, ${ }^{95}$ it would suggest that the criticisms of LPAs by scholars and policymakers ${ }^{96}$ might have been overblown. How could this be the case? One explanation could be that the vague and open-ended terms that have historically been in LPAs were that way simply because private equity funds typically last a long time and are therefore necessarily incomplete contracts. ${ }^{97}$ Trying to foresee all of the many contingencies that can arise over a fund's ten-year life span, let alone craft contractual arrangements for each of those contingencies,

the industry's lobby group."); Neil Weinberg \& Darrell Preston, Look Who's Coming to Private Equity's Defense on Fee Secrecy, BLOOMBERG BusINESSWEEK (Aug. 25, 2016), https://www.bloomberg.com/news/articles/2016-08-25/look-who-s-coming-to-private-equity-s-defenseon-fee-secrecy [https://perma.cc/TA4H-B9DY] (“'The terms of industry contracts are negotiated over months between sophisticated parties,' says James Maloney, a spokesman for the American Investment Council, a private equity trade group in Washington.”).

92. See infra Section III.B.1.

93. For foundational analyses of the doctrine of freedom of contract, see generally Morris R. Cohen, The Basis of Contract, 46 HARV. L. Rev. 553 (1933), and Roscoe Pound, Liberty of Contract, 18 YALE L.J. 454 (1909).

94. See supra note 10.

95. As noted above, I am not arguing in this Article that strong process-based arguments do not exist. Rather, I am simply challenging the particular negotiation-based defense raised by the industry, which assumes that large investors can be relied on to demand LPA terms that will benefit all investors in a fund. See supra note 20.

96. To be clear, this Article is focusing on criticisms of LPAs themselves, not on criticisms of other activities by managers that could be viewed as breaches of LPA terms.

97. The literature of incomplete contracting is deep and various theories exist beyond those discussed in the body of the text above. See, e.g., Ronald J. Gilson et al., Contracting for Innovation: Vertical Disintegration and Interfirm Collaboration, 109 ColuM. L. REv. 431 (2009); Oliver Hart \& John Moore, Contracts as Reference Points, 123 Q.J. ECON. 1 (2008); Kathryn E. Spier, Incomplete Contracts and Signaling, 23 RAND J. ECON. 432 (1992); Maija Halonen-Akatwijuka \& Oliver Hart, Continuing Contracts (Aug. 2016) (unpublished article), https://ssrn.com/abstract=2833362. 
can be very difficult and costly. ${ }^{98}$ In the case of portfolio fees, for example, it could have been the case that at the time of contracting, investors and managers lacked the information necessary to fully determine the appropriate amount of compensation, and that some amount of flexibility and discretion was needed. This would be consistent with findings in the procurement literature, which highlights the importance of allowing agents to charge ex-post adaption costs..$^{99}$ Another explanation for vague terms could be grounded in measurement and verification challenges. ${ }^{100}$ It could have been the case that the level of performance which the investors and manager jointly deemed satisfactory was more complex or nuanced than courts would be able to discern. Rather than run the risk of courts misinterpreting the parties' intentions, parties may have preferred to put vague standards in the LPA and rely on reputational incentives instead of terms that can be litigated.

Plausible explanations for some of the other controversial elements of private equity LPAs can also be imagined. Accordingly, evaluating process rather than substance in this area may not actually be a bad idea. Judging the substantive quality of LPA terms as an outside observer is inherently difficult, and no outside critic can claim to know what the optimal substantive terms for every LPA should be (though many, as shown above, have certainly weighed in). ${ }^{101}$ Nevertheless, for the reasons developed in Part III, the process-based negotiation defense put forward by the industry is not a sufficient defense in and of itself.

\section{Problems with the Myth}

The private equity industry's frequent invocation of the negotiation myth ${ }^{102}$ demands a closer look at the role of bargaining power and negotiation in private equity funds. The myth assumes that investors with bargaining power in private equity funds use their bargaining power to demand robust and

98. For early work discussing the relationship between transaction costs and incomplete contracts, see, for example, R.A. Dye, Costly Contract Contingencies, 26 INT'L ECON. REV. 233 (1985), and Oliver Williamson, Transaction-Cost Economics: The Governance of Contractual Relations, 22 J.L. \& ECON. 233 (1979).

99. See, e.g., Patrick Bajari, Stephanie Houghton \& Steven Tadelis, Bidding for Incomplete Contracts: An Empirical Analysis of Adaptation Costs, 104 AM. ECON. REV. 1288 (2014); Patrick Bajari \& Steven Tadelis, Incentives Versus Transaction Costs: A Theory of Procurement Contracts, 32 RAND J. ECON. 387 (2001); Keith Crocker \& Kenneth Reynolds, The Efficiency of Incomplete Contracts: An Empirical Analysis of Air Force Engine Procurement, 24 RAND J. ECON. 126 (1993).

100. In certain kinds of arrangements, it will be difficult for the parties to specify their respective duties in the contract such that they can be verified by a third party like a court. In these cases, rather than leave enforcement of the parties' obligations to a court whose decisions may be unpredictable or incorrect, parties may prefer to rely on their own methods of recourse, including the parties' incentive to maintain a good reputation and ability to walk away from doing further business with the counter-party. See Douglas Bernheim \& Michael D. Whinston, Incomplete Contracts and Strategic Ambiguity, 88 AM. ECON. REV. 902 (1998).

101. See supra Section II.A.

102. See supra note 91 and accompanying text. 
adequate LPA protections that all investors can enjoy. This Part challenges that assumption. ${ }^{103}$

\section{A. Large Investors Cannot Be Counted on to Negotiate LPAs}

\section{Why Large Investors Have Bargaining Power}

Before we can assess how investors use bargaining power, we first need to identify which investors have bargaining power. Because the securities laws establish minimum net worth requirements for investing in a private equity fund, ${ }^{104}$ "ordinary" people typically do not invest in private equity funds under the current rules. ${ }^{105}$ The securities laws do, however, allow for an extremely wide range of investors. On the one hand, private equity fund investors can include individuals like entrepreneurs, doctors, and lawyers, and small institutions like modestly sized pension plans, endowments, and foundations (as long as they have at least $\$ 5$ million in assets). ${ }^{106}$ On the other hand, the ten institutions with the greatest exposure to private equity in 2017 each had between $\$ 21$ billion and $\$ 52$ billion allocated to the private equity asset class and total assets in the hundreds of billions. ${ }^{107}$ When compared with the largest

103. A description of various forms of individualized benefits that can be negotiated for in private equity funds can be found in Section III.D.

104. The current minimum standards for investing in private equity funds are rooted in private equity managers' desire to avoid registering under the federal securities laws, as registration imposes obligations on managers that are costly and incompatible with the business plan and management structure of a typical private equity fund. See SCHELL ET AL., supra note 39, $\$ 8.03$ ("[T] he substantive requirements imposed on registered investment companies are not compatible with the business plan and management structure of a typical private equity fund."). To avoid registration under the Securities Act of 1933, all of a fund's investors typically must be "accredited investors" meeting certain net worth thresholds (\$5 million for most entities and \$1 million for individuals). See 17 C.F.R. § 230.501(a) (2019) (defining "accredited investor"). But see infra note 181. Registration under the Investment Company Act of 1940 (the "Investment Company Act") can be avoided if a fund has fewer than 100 investors or, alternatively, if a fund's investors are all "qualified purchasers" who satisfy a different set of net worth thresholds (generally \$25 million for entities and \$5 million for individuals). See Investment Company Act of 1940 § 3(c)(1), 15 U.S.C. § 80a-3 (2018) (imposing no sophistication requirements for funds with fewer than 100 investors); $i d$. § 3(c)(7) (allowing a fund to raise an unlimited amount of money from an unlimited number of investors if they are all "qualified purchasers"). Various other exemptions to the Investment Company Act exist, but these are the most commonly used. Furthermore, if managers want to charge carried interest, their investors must also meet the "qualified client" standard set forth in Rule 205-3 of the Advisers Act, which currently requires entities and natural persons to have a net worth of at least $\$ 2$ million or an investment with the manager of at least \$1 million. 17 C.F.R. § 275.205-3 (2019).

105. Of course, as noted above, the SEC is currently in the process of considering changes to these rules that would make them more permissive. See supra notes 23 and 24.

106. Available evidence suggests that small institutional investors, which often invest on behalf of middle-class workers, universities, and charitable institutions, are regular investors in today's private equity funds. See, e.g., Joseph Borda, Endowment Plans' Private Equity Allocation by Assets Under Management, PREQIN (Jan. 26, 2016), https://www.preqin.com/blog/0/13413/endowments-inprivate-equity [https://perma.cc/8DV2-LG3C] (reporting the results of a survey showing that small endowments with less than $\$ 500$ million in assets represented $60 \%$ of all endowment plans investing in private equity funds, but only $6 \%$ of the total capital invested by endowments in private equity).

107. See Preqin, Global Private Equity \& Venture Capital RePort 93 (2017). 
investors, investors that would seem quite substantial in any other context will be relatively small in many private equity funds.

Large investors generally have greater bargaining power with private equity fund managers than smaller investors for two reasons. First, having a large amount of investable assets can give an investor greater bargaining power. ${ }^{108}$ When managers know that an investor has a large amount of capital that could be invested in the manager's future funds or other product offerings, ${ }^{109}$ they will be more inclined to accommodate its requests in order to keep that investor happy. In addition, larger institutions that make a higher volume of private equity investments are more likely to have larger investment teams available to negotiate their private equity fund investments - so they are likely to be more inclined to use their bargaining power. ${ }^{110}$

Second, large investors have greater bargaining power with managers because they tend to make larger investments in each individual fund that they invest in. The size of an investment has two important effects. One, it increases an investor's bargaining power with a fund manager because that manager will have more to lose if the investor chooses to walk away from the investment. Two, when an investor makes a larger investment in a fund, that investor will find it easier to justify spending on legal and other advisory expenses necessary to negotiate the terms of that investment. For example, if an investor makes a $\$ 100$ million investment in a fund, spending $\$ 50,000$ in legal fees to negotiate the terms of that investment will repay itself if it leads to a $0.05 \%$ increase in the value of the investor's overall investment. But if an investor is making a $\$ 100,000$ investment in a fund, spending $\$ 50,000$ in legal fees will only make sense if it generates at least a 50\% increase in the value of the investor's overall investment-which is clearly far less likely to happen. For both of these reasons, when an investor makes a larger investment in a fund, they are more likely to engage in negotiations over the terms of that investment.

108. See Aleksander Andonov, Rob Bauer \& Martijn Cremers, Can Large Pension Funds Beat the Market? Asset Allocation, Market Timing, Security Selection, and the Limits of Liquidity (Network for Studies on Pensions, Aging \& Ret., Working Paper No. 62, 2012), https://ssrn.com/abstract=2214931 [https://perma.cc/J3QC-88QL] (finding that larger funds can assert more negotiation power in alternative asset classes than smaller investors).

109. Many private equity managers offer different funds focusing on a wide range of strategies and industries. See Andrew Tuch, The Remaking of Wall Street, 7 HARv. Bus. L. REv. 315 (2017) (noting the expansion and diversification of private equity firm activities); Helen Thomas, Carlyle Buys 55\% in Credit Investor Claren Road, FIN. TIMES (Dec. 6, 2010), https://www.ft.com/content/2122b8820162-11e0-8392-00144feab49a [https://perma.cc/7AX2-VEVV] ("Many of the world's biggest private equity groups are diversifying geographically and pushing into different asset classes as they seek to enlarge the range of products they can offer investors.").

110. Cf. Morris \& Phalippou, supra note 57, at 74 ("Many private equity investors are small. They may have just one person allocating capital to private equity, who may also be responsible for other alternative investments. These institutions may simply lack the resources to benchmark complex contracts, performance data and the like."). 


\section{Diminished Incentives to Negotiate LPA Terms}

While it is true that most large investors have at least some bargaining power, their incentives to negotiate fund agreements may often be weaker than the negotiation myth suggests. ${ }^{111}$ This is because large investors have strong incentives to use their bargaining power to negotiate for personal benefitsbenefits that they do not need to share with other investors in the funds-before they expend their bargaining power on the terms in LPAs. ${ }^{112}$

Why is this? Unlike large investors in a corporation, ${ }^{113}$ it is extremely common for large private equity fund investors to negotiate for various forms of individualized benefits in private equity funds, ${ }^{114}$ where the benefit of the negotiated bargain is not shared with all of the other investors in the fund. These benefits are typically documented in a "side letter" to the LPA, which modifies the terms of the LPA as they apply to the investor that is the recipient of the side letter. ${ }^{115}$

If we assume that large private equity fund investors have a finite amount of bargaining power, ${ }^{116}$ and that they want to use their bargaining power in a manner that maximizes their personal benefit, negotiating for strong fund-wide protections will usually be a second-best use of that bargaining power from an efficiency perspective. Instead, a large investor will generally be better off using its bargaining power to obtain as many individualized benefits as possible before it "spends" its bargaining power on benefits that other investors will also enjoy. In this context, an "efficient" use of bargaining power refers to one that achieves as much personal benefit as possible in return for the investor's bargaining power.

111. This assessment is consistent with anecdotal observations by Leo Strine, Chief Justice of the Delaware Supreme Court, and Travis Laster, Vice Chancellor of the Delaware Chancery Court. See Strine \& Laster, supra note 21 , at 11 ("Based on the cases we have decided and our reading of many other cases decided by our judicial colleagues, we do not discern evidence of arms-length bargaining between the sponsors of the alternative entities and the investors in the governing instruments of alternative entities that raise capital from diverse investors.... [B]argaining, at best, occurs only sometimes.").

112. To be clear, I am not saying that LPAs are never negotiated. Rather, I am saying that LPA terms are unlikely to be a very high priority when large investors are deciding how to use their bargaining power.

113. See supra note 11 .

114. Section III.D provides a short summary of many of the individualized benefits that large investors can negotiate for in private equity funds.

115. See SCHELL ET AL., supra note 39, § 11.14 ("A side letter is an agreement between a Fund and one of its investors, which establishes a series of investment terms that supplement or modify the terms of the partnership agreement with respect to that investor.”). Because separately managed accounts are distinct entities from any pooled funds, they typically have their own LPAs and therefore are not provided for in side letters.

116. The validity of this premise seems self-evident. When a manager negotiates with a large investor, it will be willing to make certain concessions to that investor due to its size and influence. However, at the point when the requested concessions outweigh the expected benefit that the manager expects to receive from the large investor's investment, the manager will push back on the request or reject the investor's investment. 
This claim is grounded in the idea that whenever an investor seeks a term in an LPA that would benefit all investors in the fund, it will generate asymmetric value and costs between the large investor and the manager. This asymmetry will be created anytime the negotiating investor would enjoy only a fraction of the benefit provided by a requested LPA protection (because that investor holds only a partial ownership interest in the fund), while the manager would bear the whole corresponding cost of that protection. Even though an investor may be able to persuade a manager to grant concessions that have asymmetric benefits and losses, more of that investor's bargaining power will be exhausted in the process. In other words, the greater the loss that a requested protection will inflict on a manager, the more bargaining power a large investor will have to spend to obtain that protection.

For example, consider a case where a large investor wants to insert a term into the LPA ensuring that the manager's fiduciary duties to investors under state law have not been waived or modified by any provisions in the LPA. ${ }^{117}$ Assume that this term will restrict the manager's activities in a manner that will result in a $\$ 1$ million loss for the manager over the life of the fund and a $\$ 1$ million gain for the overall fund. However, because the requesting investor only owns a portion of the pooled fund, that investor will only enjoy a fraction of the benefit generated by this affirmation of the manager's fiduciary duties. For example, if the negotiating investor owns a $10 \%$ interest in the fund, bargaining for this affirmation will generate a $\$ 100,000$ benefit for the negotiating investor and will impose a \$1 million loss on the manager, as illustrated in Figure $\mathrm{C}$ below.

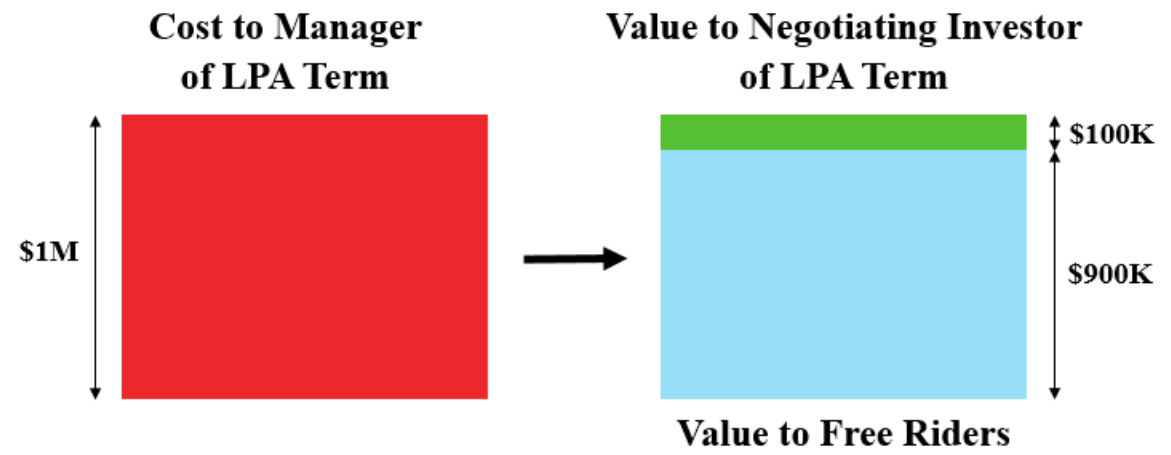

Figure $\mathrm{C}$

If, however, instead of requesting an LPA provision that affirms the manager's fiduciary duties, the large investor were to ask the manager to give it the expected value of the affirmation $(\$ 100,000)$ in the form of an

117. See supra notes 72-74 and accompanying text for a discussion of the common practicing of modifying and waiving fiduciary duties under state law. 
individualized deal that is not shared with other investors, ${ }^{118}$ the picture looks different. In such a scenario, none of the value created by that negotiation would benefit free riders, and the large investor would be equally well off, as illustrated in Figure D below. This is clearly a more efficient use of the large investor's bargaining power.

A
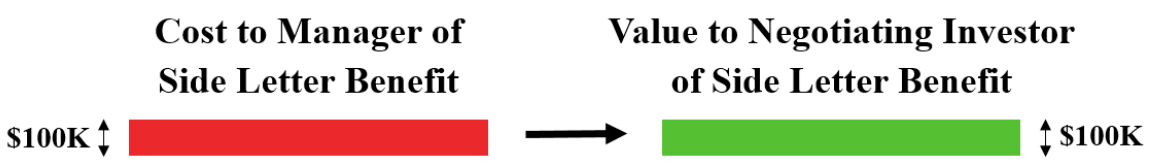

Figure D

The same logic applies when there are multiple investors that request an LPA affirming the manager's fiduciary duties. For example, in Figure E below, in addition to the $10 \%$ investor discussed above, there are three other investors who also each own $10 \%$ of the interests in the fund and who also request an affirmation of the manager's fiduciary duties in the LPA. Even though multiple investors are requesting the affirmation in this example, free riders still consume most of the benefit that is generated by the term. As a result, none of these investors will receive the full benefit of the bargaining power that they spend by negotiating for the affirmation of the manager's fiduciary duties. Each of them thus has a strong incentive to use their bargaining power to negotiate for individualized benefits rather than for an affirmation of the manager's fiduciary duties.

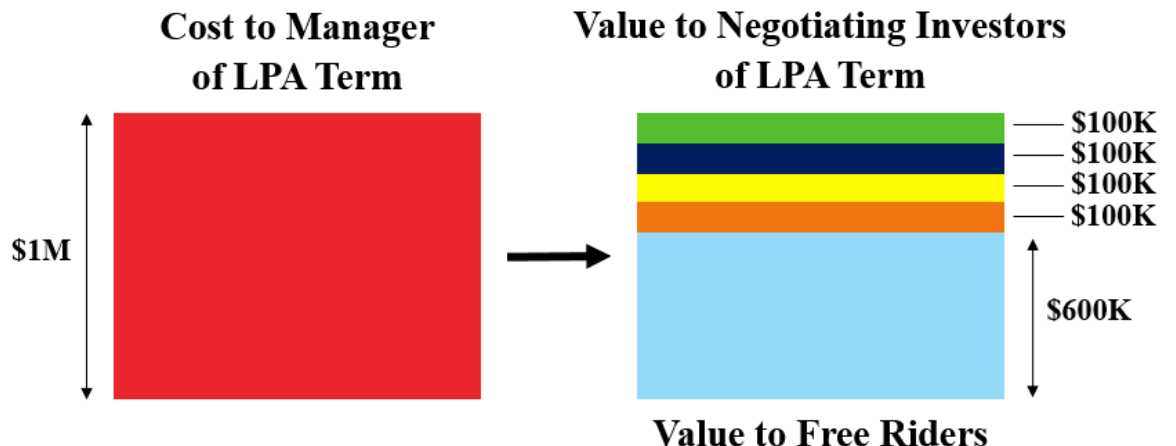

Figure E

118. A large investor could, for example, negotiate to pay less in management fees by an amount that "offsets" the expected harm from the manager breaching its fiduciary duties. If this provision only benefits the large investor, it would consume less of the investor's bargaining power than an LPA term that affirms the manager's fiduciary duties. 
At this point, readers familiar with the private equity fund contracting process might insist that the benefits conveyed in side letters often are not truly "individualized" because some of the other investors in the fund may have "most favored nation" rights. A most favored nation ("MFN") right is typically granted in an investor's side letter, and it gives that investor the right to see side letters granted to other investors in the fund and to receive the same rights and privileges given in those side letters.

However, MFN provisions usually only entitle an investor to receive the rights and privileges given to investors who have made investments in the fund of equal or lesser value. ${ }^{119}$ Because of this, the logic above still applies even when some investors have MFN rights - investors will still strongly prefer to use their bargaining power to negotiate for side letter benefits before they negotiate for LPA terms.

Let's see how the incentives of the investors in our hypothetical fundwith four $10 \%$ investors, and an assortment of smaller investors - change when all investors in the fund have MFN rights that entitle them to receive the rights given to other investors making similarly-sized investments. If one of the $10 \%$ investors negotiates for a side-letter benefit, the MFN right will kick in for investors that have made investments in the fund of the same or greater size. In this case, each of the three other $10 \%$ investors will have a right to receive the same benefit. Thus, if the negotiating $10 \%$ investor bargains for a side letter benefit worth $\$ 100,000$ in value, it will result in $\$ 100,000$ in value also going to each of the other three $10 \%$ investors, who get to free ride on the negotiation thanks to their MFN rights. Effectively, the negotiating investor will spend $\$ 400,000$ of bargaining power to obtain a $\$ 100,000$ benefit, with $\$ 300,000$ going to the free riders that have MFN rights. ${ }^{120}$ This is illustrated in Figure F below.

119. See SCHELL ET AL., supra note 39, § 11.14 ("An MFN provision usually requires the Sponsor to provide similarly-situated investors (i.e., those with equivalent Capital Commitments or regulatory circumstances) the opportunity to elect to receive the rights and benefits provided via side letter to other investors in the same Fund.").

120. The situation would be different if, for example, the negotiating investor held a $15 \%$ stake in the fund and the other three investors held $10 \%$ stakes. In this case, the $15 \%$ investor's incentives would be completely unaffected by MFN rights because no other investors in the fund would be entitled to receive the side letter terms that it negotiates for. As a result, any benefits that the $15 \%$ investor were to receive in a side letter would be truly "individualized" because no free riders would get the benefit of them. 


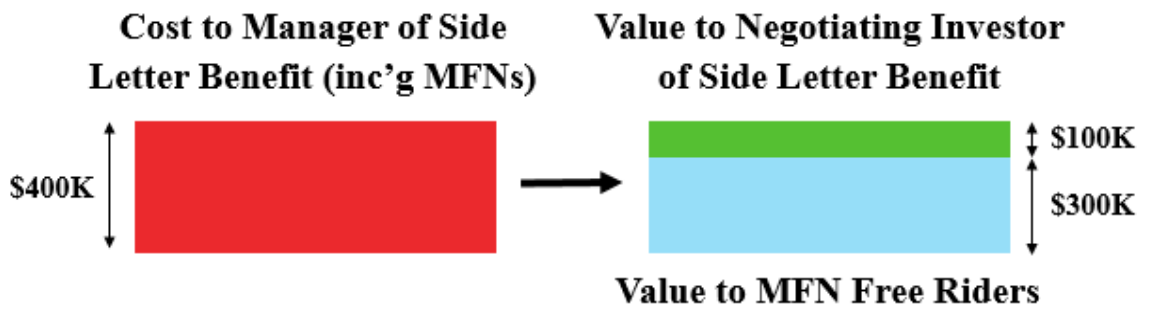

Figure F

Accordingly, if the negotiating $10 \%$ investor is deciding between negotiating for a fiduciary duty affirmation in the LPA worth $\$ 1$ million for the fund and a side letter benefit worth $\$ 100,000$, the side letter benefit will still be a far better use of that investor's bargaining power. Whereas the side letter benefit will result in $\$ 300,000$ in value going to free riders, the affirmation in the LPA will result in $\$ 900,000$ in value going to free riders, as illustrated in Figure $\mathrm{C}$ above. ${ }^{121}$

The analysis above does not suggest that large investors do not review the protections in LPAs or that they are indifferent to them. What it does show is that if a large investor can quantify the expected cost of a weak LPA protection, it has strong incentives to use its bargaining power to recover that expected lost value through individualized benefits before it seeks to negotiate for a more robust protection in the LPA. Only after the universe of potential individualized benefits has been exhausted will it make sense for a large investor to seek to negotiate for improved protections in the LPA.

Of course, the strength of this incentive will differ from fund to fund, depending on the size of the fund and the availability of individualized benefits. In general, the larger a fund, the greater the disincentive to negotiate the terms in that fund's LPA. As an individual investor's percentage interest in a fund goes down, the more free riders there will be who benefit when that investor negotiates for an improved LPA term. For example, consider a fund with only two investors (let's call them Investor 1 and Investor 2) that each have a 50\% interest in the fund. In this fund, the disincentive to negotiate will be relatively weak. If Investor 1 negotiates for an LPA term affirming the manager's fiduciary duties, for example, $50 \%$ of the value from Investor 1's negotiation will go to Investor 2, who did not negotiate for that term. By contrast, if the fund is much larger and Investor 1 only holds a 5\% interest in it, $95 \%$ of the value from Investor 1's negotiation will go to the fund's other investors. This will be a much less efficient use of Investor 1's bargaining power, and Investor

121. This assumes that no other investors are demanding the same LPA term. 
1 will have even stronger incentives to negotiate for individualized benefits before it seeks to negotiate LPA terms. ${ }^{122}$

\section{Most Important Protections Are Least Likely to Be Negotiated When} There Is Information Asymmetry

The discussion above argues that large investors' incentive to negotiate is diluted, but not necessarily eliminated, by the presence of individualized benefits. Interestingly, in situations where the manager has better information about the true value of certain LPA protections than investors, we can expect that the most important protections that are subject to this information asymmetry will be the ones that are least likely to be negotiated.

For example, in the fiduciary duty affirmation scenarios discussed above, we assumed that both the bargaining investors and the manager knew the relative costs and benefits of the protection - such that all bargaining parties knew that the fiduciary duty affirmation would impose an expected cost on the manager of $\$ 1$ million and would bring an expected benefit of $\$ 1$ million to the fund investors collectively. But this assumption might not always be true. Consider an example where the manager expects to breach its fiduciary duties in a manner that would result in a $\$ 5$ million loss to the fund (and a $\$ 5$ million gain for the manager), but the bargaining investors think it will only result in a $\$ 1$ million loss. ${ }^{123}$ Under these circumstances, the manager will have strong incentives to respond to any requests for a fiduciary duty affirmation in the LPA with an individualized counter-offer. In this case, if the manager were to offer the requesting investor an individualized benefit worth $\$ 1$ million instead of adding a fiduciary duty affirmation to the LPA, the manager would be $\$ 4$ million better off than if it had granted the fiduciary duty affirmation in the LPA.

When a protection would restrict an activity that the manager actually expects to engage in, the manager will be more reluctant to agree to provide that protection in the LPA, and more likely to insist on providing an individualized benefit instead. In these cases, the manager has more to lose from granting the robust LPA protection, and the fund investors as a whole have more to gain from including the LPA protection (even though they do not know it). As a result, it is precisely the most important terms in the LPA-the ones that protect against activities that are most likely to extract value from the fund - that are the least likely to be negotiated when this kind of information asymmetry exists.

122. This is a form of collective-action problem in private equity funds that gets worse as the fund gets bigger.

123. This could be related to potential conflicts of interest or other issues implicating fiduciary duties that the manager anticipates facing in the future, but which are not apparent to investors now. 
This dynamic may help to explain some of the LPA deficiencies that the SEC uncovered in its sweeping examination of the industry. ${ }^{124}$ Whereas large investors may have thought that the vague fee terms and weak disclosure requirements in LPAs were only likely to generate a modest amount of cost to the fund, managers might have viewed them as a much more valuable source of revenue. This may have given managers a strong incentive to offer individualized benefits instead of agreeing to more robust fee and disclosure provisions in LPAs, while investors may not have been aware of how much value they were actually giving up.

\section{B. Large Investors Cannot Be Counted on to Vote with Their Feet}

The private equity negotiation myth assumes that large investors will use their influence to ensure that LPAs have high-quality protections. Above, I questioned whether large investors can be relied on to engage in robust negotiations for strong fund protections. But more analysis is needed. Even when large investors choose not to negotiate LPAs, they could still wield influence by choosing to walk away from funds that have weak terms. Because large investors make large investments, managers might still be sensitive to their preferences even if they are not actively negotiating for their demands.

Below, I show why we cannot assume that large investors will wield this kind of non-bargaining influence, either. In private equity funds, when large investors have bargaining power, it can make them less sensitive to the quality of LPA protections because it enables them to negotiate for individualized benefits that offset the harm caused by weak protections. This can make them more willing to invest in funds with sub-optimal protections than if they lacked bargaining power altogether. As a result, the marginal investors in private equity funds may sometimes be ones that lack bargaining power, rather than the ones that have it.

\section{How Contract Terms Are Shaped in the Absence of Negotiation}

The vast majority of commercial contracts in the modern economy are not negotiated. ${ }^{125}$ But this does not necessarily mean they have unfair terms. Throughout the marketplace, parties frequently sign contracts without negotiating their terms, opting instead to make take-it-or-leave-it decisions based on the quality of the offered terms and the seller's reputation.

In contracting settings where the parties do not negotiate, the quality of a contract's protections are shaped by the preferences of that market's "marginal"

124. See supra Section II.A.3.

125. See John J. A. Burke, Contract as Commodity: A Nonfiction Approach, 24 SETON HaLL LEGIS. J. 285, 290 (2000) ("[I]n an advanced economy the standard form contract accounts for more than $99 \%$ of all contracts used in commercial and consumer transactions for the transfer of goods, services and software."). 
buyers. ${ }^{126}$ Marginal buyers are those that care most about the contractual protections and are most likely to stop buying a product when the quality of the contractual protections go down. ${ }^{27}$ Accordingly, in situations when the protections in a private equity fund LPA are not heavily negotiated, the quality of those protections will be determined by how sensitive the industry's marginal investors are to LPA protections. ${ }^{128}$

If the marginal investors in private equity funds are informed and rational, it means that some quantity of less informed and less rational investors can also invest in private equity funds without upsetting the quality of the contract's terms. These investors can effectively "free ride" on the marginal investors, enjoying the benefit of high-quality LPA protections even if they would have been willing to buy the product with lower-quality terms. ${ }^{129}$ Identifying the marginal investors in private equity funds thus has important policy ramifications.

\section{Large Investors Won't Always Be the Marginal Investors}

For the reasons mentioned above, even if large investors are not actively negotiating the terms of LPAs, they could still be regulating the quality of LPA protections by consistently choosing to "vote with their feet" by walking away from funds with weak protections. If this is true, then the private equity negotiation myth may not be so misleading after all. The myth might get the details wrong by focusing on the act of negotiation but lead to the right conclusion by stating that large investors are demanding (in one way or another) high-quality LPA protections.

Unfortunately, this cannot be assumed, either. In reality, large investors cannot be relied on to serve as the marginal investors with respect to LPA

126. This assumes that the market is competitive. See Cole, supra note 14, at 414 ("[N]onprice terms, like price terms, are 'policed' in competitive markets by the marginal consumer for each term. Competitors failing to capture the marginal consumer for such terms under competitive market conditions suffer the same fate as sellers who fail to compete on price.").

127. See supra note 15 and accompanying text.

128. See Richard Craswell, Passing on the Costs of Legal Rules: Efficiency and Distribution in Buyer-Seller Relationships, 43 STAN. L. REV. 361, 373 (1991) ("In markets where different consumers attach different values to a warranty, the size of the accompanying price increase will be determined largely by the valuations held by those consumers who are on the margin between buying or not buying the product/warranty package. These consumers, the marginal consumers, will stop buying the package if its price rises; consequently, the willingness to pay of marginal consumers will determine how high the price of the combined package will rise.").

129. See Michael J. TRebilcock, The Limits of FreEdom of Contract 120 (1993) (“To the extent that there is a margin of informed, sophisticated, and aggressive consumers in any given market, who understand the terms of the standard form contracts on offer and who either negotiate over those terms or switch their business readily to competing suppliers offering more favourable terms, they may in effect discipline the entire market, so that inframarginal (less well informed, sophisticated, or mobile) consumers can effectively free-ride on the discipline brought to the market by the marginal consumers . . . ."); Alan Schwartz, How Much Irrationality Does the Market Permit?, 37 J. LEGAL STUD. 131, 131 (2008) (finding that "when enough consumers are sophisticated and the naïve have a relatively low willingness to pay for their preferred contract, exploitative contracts decline in frequency and may actually vanish"). 
protections in private equity funds. ${ }^{130}$ A close evaluation reveals that when large investors have bargaining power, it can make them more likely to tolerate funds with weak terms than if they had no bargaining power at all. To illustrate, Investor A below requires a total expected net present value ("NPV") of $\$ 100,000$ from investing in Fund $\mathrm{Z}$ or it will walk away from making the investment. Before considering the effect of sub-optimal LPA protections, an investment in Fund $\mathrm{Z}$ has an expected NPV of $\$ 200,000$, as illustrated in Figure $\mathrm{G}$ below.

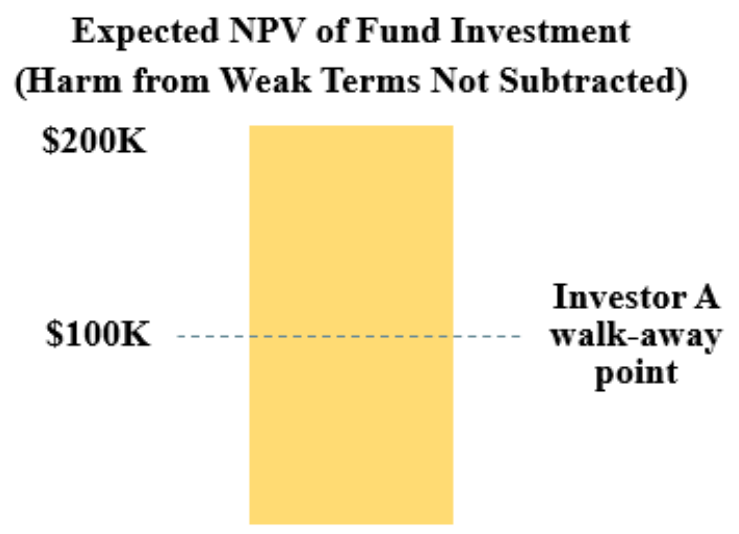

Figure G

However, Fund $\mathrm{Z}$ has suboptimal LPA protections which decrease the expected NPV of an investment in Fund $Z$ by $\$ 175,000$. These sub-optimal protections could include, for example, an open-ended provision allowing Fund Z's manager to charge unlimited portfolio company fees and an explicit waiver of the Fund Z manager's fiduciary duties. This brings the expected NPV of an investment in Fund $Z$ down to $\$ 25,000$, well below Investor A's walk-away point. This is illustrated in Figure $\mathrm{H}$ below, with the shaded rectangle representing the lost expected value resulting from sub-optimal terms.

130. Because the concept of a marginal investor is theoretical, it is impossible to determine with certainty who the "true" marginal investors are in any particular market. See Cole, supra note 14, at 420 ("The marginal consumer - that one consumer for whom all of the suppliers compete-is unknown to the suppliers. All they know is that the marginal consumer is out there."). 


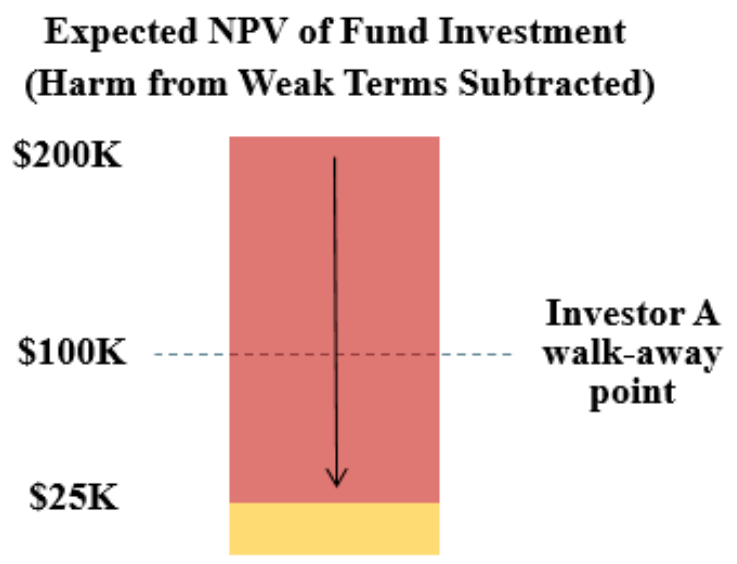

Figure $\mathrm{H}$

If Investor A does not have any bargaining power, the sub-optimal protections in Fund Z's LPA will certainly cause Investor A to walk away from an investment in Fund $Z$. The harm from the sub-optimal protections in Fund Z's LPA bring the expected NPV of Fund Z far below Investor A's walk-away point.

This conclusion can change, however, if Investor A has bargaining power. As discussed above, ${ }^{131}$ if Investor A has bargaining power, it will have strong incentives to use it to negotiate for individualized benefits before it directly negotiates to improve the LPA protections in Fund Z. If Investor A can negotiate for individualized benefits - in the form of fee discounts, rights to coinvestment opportunities, or otherwise ${ }^{132}$ - of at least $\$ 75,000$, it will go ahead and invest in Fund $\mathrm{Z}$ despite the weak LPA protections. When its individualized benefits exceed $\$ 75,000$, Investor A's expected NPV from investing in Fund $\mathrm{Z}$ will exceed its walk-away point of $\$ 100,000$. Thus, even though Investor $\mathrm{A}$ would have walked away from Fund $\mathrm{Z}$ if it lacked bargaining power, there is a good chance that it will proceed with the investment if Fund Z's manager is willing to grant individualized benefits when Investor A requests them.

Now consider Investor B. Investor B is smaller than Investor A. It has no bargaining power to negotiate for individualized benefits. It also has fewer attractive outside investment opportunities than Investor A, so it is willing to accept a lower expected NPV for its investment in Fund $Z-\$ 50,000-$ before it will walk away from making the investment. This is illustrated in Figure I below.

131. See supra Section III.B.1.

132. See infra Section III.D. 


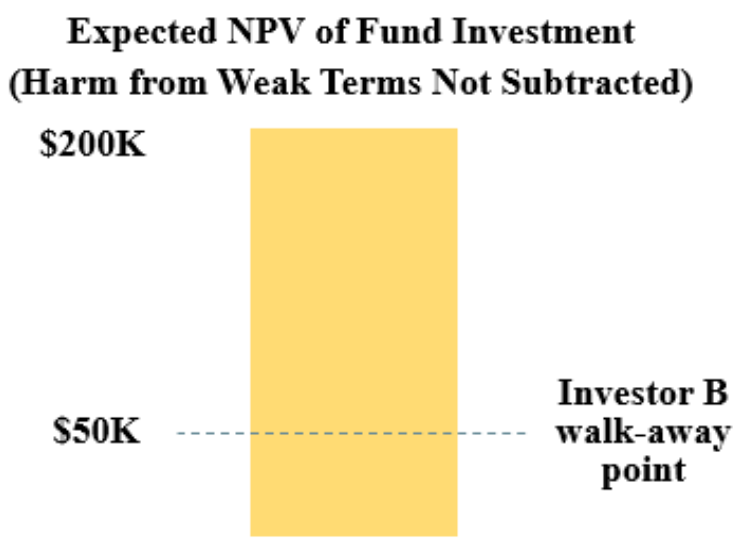

Figure I

However, after the harm caused by the sub-optimal terms in Fund Z's LPA is taken into consideration, the expected NPV of investing in Fund $\mathrm{Z}$ of $\$ 25,000$, which is lower than Investor B's walk-away point of $\$ 50,000$. This is illustrated in Figure J below.

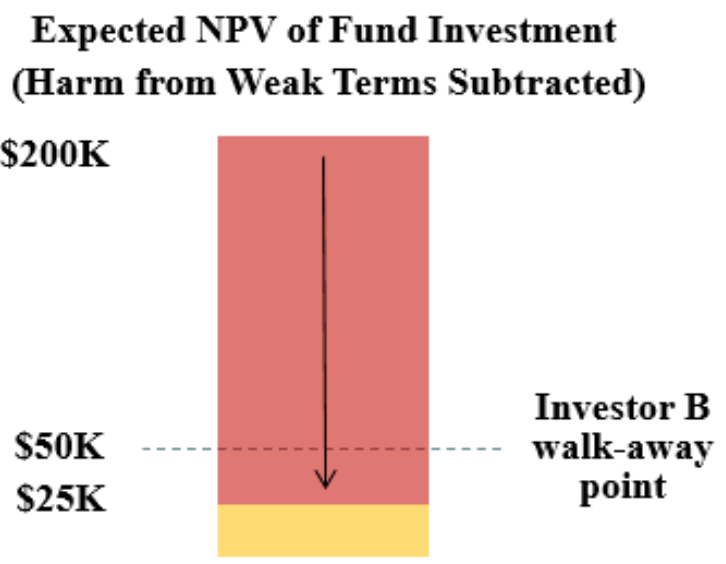

Figure $\mathbf{J}$

Since Investor B does not have bargaining power to negotiate for any individualized benefits that would offset the harm caused by the sub-optimal terms, Investor B really will walk away from Fund Z, unlike Investor A.

The examples above show how bargaining power can cause investors to tolerate weaknesses in LPAs that they otherwise would not tolerate. In this case, without bargaining power, Investor $A$ would have been more sensitive than Investor B to weaknesses in Fund Z's LPA because its walk-away 
threshold was much higher than Investor B's. But because it can negotiate for individualized benefits, Investor A can get comfortable with investing in Fund $\mathrm{Z}$ if the manager is willing to grant it a relatively modest amount of individualized benefits. ${ }^{133}$ Investor B, by contrast, will definitely walk away from Fund Z, despite the fact that Investor B's walk-away point is much lower than Investor A's.

Because of this, it cannot be assumed that the largest investors in private equity funds are the ones that always shape the quality of LPA protections. Large investors' bargaining power can make them less sensitive to the quality of LPA protections and less likely to walk away from funds with weak terms. This means that the marginal investors in private equity funds may often be investors that lack bargaining power, rather than those that have it. ${ }^{134}$ Thus, by focusing attention on large investors, the private equity negotiation myth directs policymakers to look in the wrong places when making policy decisions that affect the private equity industry.

\section{Agency Problems Can Reduce Incentives to Demand Strong Protections}

All of the analysis above assumes that large investors act rationally to maximize returns for their beneficiaries when they make decisions about how to utilize their bargaining power. This may not, however, always be true. In public pension plans - the largest investors in the private equity industry ${ }^{135}-$ pension staff members have sometimes been shown to suffer from agency problems that affect the way they manage plans. ${ }^{136}$

Pension staff members' personal career concerns could plausibly make them less likely to demand strong protections for their plan beneficiaries. On the one hand, for any individual employee, personal career benefits from aggressively demanding a better fund agreement protection are likely to be limited, as the value of that protection may not be realized for many years to come, if and when the potential risk addressed by that protection ever materializes. But on the other hand, if that employee's insistence on the stronger protection causes some managers to reject the plan and refuse to accept its capital, there could be immediate career consequences for the employee. This is particularly true if other pension plans in the market are

133. This assumes that Investor A can obtain at least $\$ 75,000$ in individualized benefits, as the example shows.

134. This is an important distinction if we expect that larger investors have more resources and will be more willing to invest time and resources into reviewing LPA terms than smaller investors. One study suggests that this is the case. See Da Rin \& Phalippou, supra note 28, at 65 ("[T]he only consistently significant dimension along which LPs differ in their practices is the size of the private equity portfolio (in absolute value). The institutions with large allocations to private equity are those spending most time on due diligence for each fund and those undertaking the most initiatives in the due diligence process.").

135. See supra note 7.

136. See supra note 18. 
choosing not to demand the same protections. ${ }^{137}$ Accordingly, even when it would be optimal for a plan's beneficiaries to demand stronger terms, pension employees may hesitate to do so because of their own personal career concerns, creating a status quo bias in the market for LPA terms.

\section{Forms of Individualized Benefits in Private Equity}

The incentives described in Sections III.A and III.B above will only exist when large investors can negotiate for individualized benefits. To the extent that a fund's manager refuses to grant or otherwise limits individualized benefits, large investors will be more likely to demand strong LPA protections. However, available data suggests that individualized benefits are quite common in the private equity fund industry and are therefore likely to play a significant role in shaping large investors' incentives. These individualized benefits can take various forms. Below, I briefly describe some of the individualized benefits that managers commonly grant to investors in side letters. ${ }^{138}$

\section{Fee Discounts}

Fee discounts are a standard practice in the private equity marketplace. ${ }^{139}$ Fee terms are commonly viewed as the most heavily negotiated terms when investors make investments. ${ }^{140}$ Large investors most commonly negotiate for discounts to management fees, but discounts to carried interest are sometimes granted as well. ${ }^{141}$ Fee discounts are entirely legal as long as managers disclose the possibility of differential fee treatment to the fund's investors. Unlike

137. While pension staffs are supposed to be overseen by boards of trustees, research has shown that trustees are often driven by political incentives that deviate from the interests of plan beneficiaries. See, e.g., Aleksandar Andonov, Yael Hochberg \& Joshua D. Rauh, Political Representation and Governance: Evidence from the Investment Decisions of Public Pension Funds, 73 J. FIN. 2041 (2018) (finding that public pension fund boards heavily populated by politically appointed trustees invest in private equity funds that deliver lower returns).

138. See supra note 115.

139. See Wulf A. Kaal, Private Fund Fee Structure and Blockchain Applications, in LOWELL MilKen INST. FOR BUS. LAW \& POLICY, UCLA SCH. OF LAW, PRIVATE EQUITY Fund REPORT 15, 15 (2017), https://lowellmilkeninstitute.law.ucla.edu/wp-content/uploads/2017/05/Private-FundConference-2017_FINAL.pdf [https://perma.cc/5CK9-PWHD] ("It has become increasingly common in recent years for investors to negotiate fees with fund managers."); Chris Flood, Private Equity Clings to '2 and 20' Fee Model, Fin. TIMES (Apr. 12, 2016), https://www.ft.com/content/f7dc242c-58a9-11e69f70-badea1b336d4 [https://perma.cc/249Z-FNH8] ("Large investors that are prepared to commit a significant chunk of money can secure lower management fees, but smaller players simply don't have that kind of leverage.").

140. See Victoria Robson, Management Fees Most Heavily Negotiated LPA Point, PRIV. EQUITY INT'L (Feb. 17, 2016), https://www.privateequityinternational.com/management-fees-mostheavily-negotiated-lpa-point/ [https://perma.cc/MX4D-UMKH] (reporting survey results finding that management fee terms are the most heavily-negotiated terms in private equity fund negotiations).

141. Though fee discounts can come in various forms, for purposes of this Article, a basic understanding of the fact that fee discounts are commonly requested and granted is sufficient. See Kaal, supra note 139, at 15 ("Alternative fee arrangements include but are not limited to modified highwater marks, incentive hurdles, and triggers, as well as clawbacks."). 
contractual protections that benefit all investors in a fund, a large investor will internalize the full benefit of a fee discount that is not shared with other investors.

\section{Co-Investments}

"Co-investing" describes arrangements where a manager invites large investors to invest alongside the pooled fund in portfolio companies the pooled fund is investing in. Co-investments are commonly structured through vehicles that aggregate the capital of multiple co-investors for one or more deals. Coinvestment rights are commonly granted to investors that are already participating in a manager's fund through those investors' side letters. ${ }^{142}$ In such cases, the investor gains exposure to portfolio companies in two waysfirst, through its interest in the fund (which invests in the portfolio company), and second, through its "co-investment" directly in the portfolio company. ${ }^{143}$

Co-investments are attractive to investors because managers typically charge much lower fees on co-investments than they charge for investments in their pooled funds, ${ }^{144}$ with many co-investments offered on a fee-free basis. As a result, co-investments commonly outperform pooled funds on a net-of-fees basis. ${ }^{145}$ In addition, when a manager offers a co-investment opportunity, it typically gives the investor a chance to consider the opportunity and decide whether to accept or reject it. Co-investments thus provide investors with a level of control that goes far beyond their rights as investors in a pooled fund.

Managers feel competitive pressure to grant co-investment opportunities because large investors frequently demand them. ${ }^{146}$ Co-investment rights are commonly considered an important part of the overall package when investors decide whether to make an investment in a fund, ${ }^{147}$ and they have become a key

142. See Preqin, Private EQuity Co-InVestment Outlook 5 fig.6 (Nov. 2015), https://docs.preqin.com/reports/Preqin-Special-Report-Private-Equity-Co-Investment-Outlook-

November-2015.pdf [https://perma.cc/M93L-5UDC] (showing that co-investment rights are most commonly granted during the fundraising process); see also infra Appendix A.

143. See infra Appendix B for a graphic showing an illustrative co-investment arrangement.

144. See PricewaterhouseCoopers, Private Equity Co-InVestment: Best Practices EMERGING 2 (Jan. 2015), https://www.pwc.com/us/en/financial-services/regulatoryservices/publications/assets/private-equity-co-investment.pdf [https://perma.cc/LF74-7PQM] ("Coinvestors often benefit from lower (or no) management fees and carried interest, as well as greater deal selectivity and transparency.").

145. See PREQIN, supra note 7, at 55 (presenting survey results showing that (i) $98 \%$ of investors saw similar or better returns from their co-investments compared to fund returns in 2017 and (ii) investors' two most commonly cited reasons for pursuing co-investments are the expectation of lower fees and better returns than pooled fund investments).

146. Antoine Drean, The Growing Promise and Pitfalls of Private Equity Co-Investment, FORBES (July 13, 2016), https://www.forbes.com/sites/antoinedrean/2016/07/13/the-growing-promiseand-pitfalls-of-private-equity-co-investment [https://perma.cc/manage/create?folder=24184-66233] ("Competitive pressure is why the number of managers offering co-investment has grown so much.").

147. Marc Wyatt, Acting Dir., Office of Compliance Inspections \& Examinations, U.S. Sec. \& Exch. Comm'n, Address at the Private Equity International Private Fund Compliance Forum: Private Equity: A Look Back and a Glimpse Ahead (May 13, 2015), https://www.sec.gov/news/speech/private- 
part of the overall private equity marketplace. ${ }^{148}$ Just like fee discounts, when a large investor negotiates to receive a greater allocation of co-investment opportunities on better terms, it will enjoy the full benefit of that negotiation.

\section{Other Rights in Side Letters}

Fee discounts and co-investment rights are not the only individualized terms granted to investors in side letters. For example, as noted above, investors can negotiate for most favored nation rights in side letters, which effectively give an investor the benefit of any bargains made by other investors that have made similarly sized (or smaller) investments in the fund. ${ }^{149}$ This can be an extremely valuable individualized benefit.

Investors can also seek to obtain seats on the fund's advisory board. With a seat on the advisory board, an investor gains increased exposure to the fund manager and its operations, ${ }^{150}$ and it will have a right to vote if the manager seeks the advisory board's consent to certain conflicted transactions. Importantly, when advisory board members participate in such votes, they typically have no duties to other investors in the fund and are free to vote in a manner that promotes their self-interest. ${ }^{151}$

Side letters also commonly grant rights to address investors' specialized disclosure or tax needs due to their structural and/or regulatory requirements (such as laws applicable to pension plans or sovereign wealth funds, among various others), and grant opt-out rights for investments in certain restricted industries. ${ }^{152}$ Investors also sometimes negotiate for things like customized

equity-look-back-and-glimpse-ahead.html [https://perma.cc/Y8NV-EC2M] (observing that the allocation of co-investment rights "was becoming a key part of an investor's thesis in allocating to a particular private equity fund").

148. See Bain \& Co., Global Private EQuity RePORT 63 (2017), https://www.bain.com/contentassets/70fbce086b8142c2aeb1305ec8f09900/bain_report_global_private_ equity_report_2017.pdf [https://perma.cc/EL74-TF5N] ("Bain estimates that coinvestment (the largest form of shadow capital) represents $10 \%$ to $12 \%$ of traditional fund-raising . . .."); PREQIN, supra note 7 , at 54 (reporting survey results showing that $64 \%$ of fund managers offered co-investments in 2017, up from $45 \%$ in 2014 and $52 \%$ in 2015 , and that $42 \%$ of all surveyed private equity investors are actively co-investing, with $12 \%$ considering co-investing in the future); Cambridge Associates, Ready, Steady, Co-Invest (Mar. 2019), https://www.cambridgeassociates.com/research/co-investment-framework/ (estimating that co-investments composed approximately $20 \%$ of all private equity activity in 2017 ).

149. See supra note 119 and accompanying text.

150. See Claire Wilson, The Power of the LPAC, PRIV. FundS CFO (Dec. 15, 2017), https://www.privatefundscfo.com/print-editions/december-2017-january-2018-issue/the-power-of-thelpac/ [https://perma.cc/2YLM-9EY3] ("For the investor, membership [in an advisory board] is a way of gaining greater visibility into the fund's operations and access to information that is not otherwise disclosed to investors.").

151. See Claudia Zeisberger, Michael Prahl \& Bowen White, Mastering Private EQuity: Transformation VIA VEnTURE CAPITAL, MinORITy InVESTMENTS AND BuYOUTS 215 (2017) ("A fund's limited partner advisory committee generally does not owe a fiduciary duty to the fund or its limited partners.").

152. See Debevoise \& Plimpton, Private Equity Funds: Key Business, Legal and TAX ISSUES 23, (2015), https://www.debevoise.com/ /media/files/insights/news/2015/pe_fundskey\% 20business_legal_tax_issues.pdf [https://perma.cc/2VGR-74WC]. 
disclosure and special access to the manager in the form of informational meetings.

These other rights can similarly have the effect of diluting a large investor's incentive to negotiate LPA terms.

\section{Separately Managed Accounts}

An even more extreme type of individualized benefit occurs when a large investor negotiates for a "separately managed account" that exists entirely outside of a manager's pooled funds. Unlike a co-investment opportunity, which is tied to a specific deal, separately managed accounts are vehicles that are set up to make many investments over longer periods of time. The terms of a separately managed account are independently negotiated between the investor and manager. ${ }^{153}$

Separately managed accounts commonly have their own customized investment mandates, governance terms, and liquidity terms. Because the vehicle is not shared with other investors, it is easier for the investor to customize and exercise control over a separately managed account. Managers face competitive pressure to grant separately managed accounts to large investors who desire them, ${ }^{154}$ and, like co-investments, they are a large and growing part of the private equity marketplace, ${ }^{155}$ with no signs of slowing down..$^{156}$

Unlike fee discounts and co-investments, which merely diminish large investors' incentive to negotiate for pooled fund contractual protections, separately managed accounts remove large investors from pooled funds altogether. This eliminates the possibility of that investor negotiating the terms of the pooled fund's LPA because the separately managed account will be entirely separate from the pooled fund.

153. Separately managed accounts can be used by investors to gain exposure to the various investment strategies offered by a manager-including, for example, hedge fund, real estate, and credit products - without having to invest directly in the various funds managed by the manager.

154. See Anand Damodaran, Matthew Judd \& James Board, Combining Managed Accounts with Traditional Fundraising: The Key Issues, PRIV. EQUITY INT'L 26 (Apr. 2013), https://www.ropesgray.com/ /media/Files/articles/2013/03/20130326_PEI.ashx [https://perma.cc/C7Y4KAMS] ("Recently, several sophisticated large-ticket investors, ranging from sovereign wealth funds to pension funds, have developed enhanced requirements for the terms under which they are willing to commit their sizable capital.").

155. See BAIN \& Co., supra note 148, at 8 ("[S]eparately managed accounts now comprise almost $6 \%$ of private capital raised, up from $2.5 \%$ in 2006); Bowden, supra note 82 ("[M]uch of the growth in private equity is not coming from the traditional co-mingled vehicles but from separate accounts and side-by-side co-investments.").

156. See PReQIN, InVestor OUtLook: PRIVATE EQuity H1, at 13 fig.2.10 (2016), https://docs.preqin.com/reports/Preqin-Investor-Outlook-Alternative-Assets-H1-2016.pdf

[https://perma.ce/T7DB-UND9] (reporting the results of a survey showing that, among investors who had previously awarded a separate account mandate, $47 \%$ viewed separate account mandates as a permanent part of their investment strategy and 37\% were considering making separate account mandates an ongoing part of their strategies going forward). 


\section{Policy Implications}

The private equity negotiation myth reflects an effort by the industry to use a process-based argument to avoid substantive scrutiny. ${ }^{157}$ This Article, at its most basic level, aims to discourage policymakers and other industry observers from simply taking the myth at face value. It argues that just because there are large investors in the industry that have bargaining power, it cannot automatically be assumed that fund agreements will always have robust protections for all investors. ${ }^{158}$

This Article also makes important contributions to broader policy debates at both the state and federal levels. Scholars and policymakers have been reevaluating conventional approaches to regulating private markets in recent years, driven in large part by the ongoing decline of the public corporation ${ }^{159}$ and the unprecedented rise of private markets. ${ }^{160}$ Below, I discuss how a more accurate understanding of the effects of bargaining power in private equity funds changes these policy discussions.

\section{A. State Law: Waiving Fiduciary Duties in Limited Partnerships}

As noted above, private equity funds typically operate as limited partnerships. ${ }^{161}$ General partners have default fiduciary duties to the limited partners in a limited partnership, ${ }^{162}$ but in most states these duties can be modified by written agreement in the LPA. In some states, including Delaware,

157. See supra Section II.B.

158. This does not reflect a judgment about whether the substantive terms of LPAs are actually fair or not. See supra Section II.A for a summary of various critiques of the substance of LPA terms. Nor does it rule out the possibility that there might be other process-based arguments to support the idea that private equity LPAs are built on effective processes that lead to sound terms.

159. See Xiaohui Gao et al., Where Have All the IPOs Gone?, 48 J. Fin. \& QuANTITATIVE ANALYSIS 1663, 1663 (2013) (showing that from 2001-2012, there were an average of less than 100 IPOs each year in the United States, compared to over 300 IPOs per year during the 1980s and 1990s); Why the Decline in the Number of Listed American Firms Matters, ECONOMIST (Apr. 22, 2017), https://www.economist.com/business/2017/04/22/why-the-decline-in-the-number-of-listed-americanfirms-matters [https://perma.cc/6LAG-GZNL] ("A big trend in American business is the collapse in the number of listed companies. There were 7,322 in 1996; today there are 3,671.”); Andrew Ross Sorkin, C.E.O.s Meet in Secret over the Sorry State of Public Companies, N.Y. Times (July 21, 2016), https://www.nytimes.com/2016/07/21/business/dealbook/ceos-meet-in-secret-over-sorry-state-of-publiccompanies.html [https://perma.cc/767J-JU3R] (reporting the findings of the National Bureau of Research that the number of publicly listed companies dropped from 8,025 to 4,101 over approximately the last twenty years); Anne VanderMey, IPOs Are Dwindling, So Is the Number of Public Companies, FORTUNE (Jan. 20, 2017), https://fortune.com/2017/01/20/public-companies-ipo-financial-markets [https://perma.cc/DA73-GUTM] (reporting a 65\% decline in the number of U.S. initial public offerings since 2014).

160. See supra note 22 and accompanying text.

161. Most state law views limited partnerships as highly contractual in nature and defers to the terms and conditions set forth in limited partnership agreements. See, e.g., DEL. CODE ANN. tit. 6, $\S$ 17.1101(c) (2018) ("It is the policy of this chapter to give maximum effect to the principle of freedom of contract and to the enforceability of partnership agreements.").

162. See supra note 46 and accompanying text. 
they can be eliminated entirely. ${ }^{163}$ This contractarian approach has been the subject of much controversy, and a robust literature has developed on the desirability of fiduciary duty waivers in non-corporate entities. ${ }^{164}$

One of the most important commentaries in this area in recent years was published by Leo Strine, former Chief Justice of the Delaware Supreme Court, and Travis Laster, Vice Chancellor of the Delaware Court of Chancery. Strine and Laster focused their analysis on the waiver of fiduciary duties in alternative entities, which include limited partnerships and limited liability companies. ${ }^{165}$ Interestingly, Strine and Laster expressed the view that, based on the cases they have observed over the years in Delaware, alternative entity agreements appear to be more like standard form contracts than highly negotiated agreements. ${ }^{166}$ They argued that alternative entity agreements are usually offered to investors on a take-it-or-leave-it basis, and that this approach can lead to these agreements having one-sided terms, including provisions that waive the fiduciary duties of the entity's manager. ${ }^{167}$ This commentary, which struck at the heart of Delaware's long-time commitment to complete freedom of contract in alternative entities, was remarkable, particularly given the authoritativeness of the authors.

By sharing their perspective from the Delaware bench, Strine and Laster offered an extremely valuable view ${ }^{168}$ into the usually private world of

163. See supra note 49 and accompanying text.

164. See, e.g., Andrew S. Gold, On the Elimination of Fiduciary Duties: A Theory of Good Faith for Unincorporated Firms, 41 WAKE FOREST L. REV. 123 (2006); Mohsen Manesh, Contractual Freedom Under Delaware Alternative Entity Law: Evidence from Publicly Traded LPs and LLCs, $37 \mathrm{~J}$. CORP. L. 555 (2012); Sandra K. Miller \& Karie Davis-Nozemack, Toward Consistent Fiduciary Duties for Publicly Traded Entities, 68 FLA. L. REV. 263 (2016); Peter Molk, How Do LLC Owners Contract Around Default Statutory Protections?, 42 J. CORP. L. 503 (2017); Peter Molk, Protecting LLC Owners While Preserving LLC Flexibility, 51 U.C. DAVIS L. REV. 2129 (2018); Larry E. Ribstein, Partnership Governance of Large Firms, 76 U. CHI. L. REV. 289 (2009); Ribstein, supra note 74.

165. Strine \& Laster, supra note 21 . As previously discussed, private equity LPAs commonly contain provisions waiving the fiduciary duties of the fund's general partner (which is usually an affiliate of the manager).

166. See id. at 23 ("The record in actual cases rarely, if ever, reflects that any bargaining at all occurred over the governing instrument. Instead, it is almost always the case that the manager or general partner's counsel drafted the governing instrument and investors were only given the choice to sign up or not, but not to bargain over its terms.").

167. See id. ("The cases ... cast doubt on the idea that the liability standards in alternative entity governing instruments reflect a high-minded, careful consideration of the unusual role of the human beings who serve as fiduciaries of general partners and managing members. Nor do the cases suggest that these standards are the result of bargaining between entity managers who wish to limit their own liability and investors who want to be able to hold them and their human fiduciaries accountable."). Some would argue that LPAs have become even more manager-friendly since Strine and Laster's article. See Elizabeth Weindruch \& Brian Pope, Views from the LPAC, BARINGS 4 (July 2019), https://www.barings.com/assets/user/media/07.2019_ViewsFromTheLPAC.pdf [https://perma.cc/E2UF43J5] ("As partnerships have become progressively sophisticated over time, the LPA terms have gotten more granular and nuanced-and there's been a noticeable shift toward agreements that incorporate more favorable terms for the general partner.").

168. Strine and Laster's analysis, of course, is limited by the fact that it was based on anecdotal observations. Strine \& Laster, supra note 21, at 1 ("Based on the cases we have decided and our reading of many other cases decided by our judicial colleagues, we do not discern evidence of armslength bargaining between sponsors and investors in the governing instruments of alternative entities."). 
alternative entities. ${ }^{169}$ However, they left open two critical questions for private equity funds. First, Strine and Laster's account suggests that the reason investors fail to negotiate the terms of alternative entity agreements is that they have inferior bargaining power. According to Strine and Laster, investors usually sign the agreement on a take-it-or-leave-it basis, and almost never get a chance to negotiate the terms, even if they want to. ${ }^{170}$ But this cannot always be true in private equity funds. Private equity managers-particularly those with low-performing track records-will not always have such superior bargaining power vis-à-vis their investors, and there will certainly be cycles when investor demand for private equity funds is on the wane. Why, then, do Strine and Laster indicate that the Delaware courts almost never see evidence that alternative entity agreements are negotiated by investors? ? $^{171}$

This Article helps to explain that puzzle in the private equity context. It shows why private equity LPAs may not be heavily negotiated even when managers have relatively weak bargaining power. When individualized benefits are available, investors can expect to receive more value by negotiating for individualized benefits before they negotiate for better LPA terms. ${ }^{172}$ Hence, regardless of how much bargaining power managers have, negotiating the LPA is likely to be a secondary priority when large investors can negotiate for individualized benefits. This is an important distinction. It shows that limited negotiation of LPAs is not just a temporary condition that persists only during cycles when managers have strong bargaining power, but something that can exist in all cycles.

This insight fundamentally alters our understanding of the problem that Strine and Laster identify, as well as the range of policy responses that could address the problem in private equity funds. If we assume that the light negotiation of private equity fund LPAs is a consequence of managers' bargaining power, then it would be logical to conclude that the concerns raised by Strine and Laster will simply be resolved when market conditions change and investors have more bargaining power relative to managers. But this may not be true.

Second, while Strine and Laster are clear about their opinion that alternative entity agreements are not highly negotiated, they fail to explain why the absence of negotiation is a problem. As discussed above, optimal contracts

169. See Mohsen Manesh, Dictum in Alternative Entity Jurisprudence and the Expansion of Judicial Power in Delaware, in RESEARCH HANDBOOK ON PARTNERSHIPS, LLCS AND ALTERNATIVE FORMS OF BUSINESS ORGANIZATIONS 346 (Robert W. Hillman \& Mark J. Loewenstein eds., 2015) ("The vast majority of alternative entity businesses are private, rather than publicly traded.").

170. Strine \& Laster, supra note 21, at 23 ("The record in actual cases rarely, if ever, reflects that any bargaining at all occurred over the governing instrument. Instead, it is almost always the case that the manager or general partner's counsel drafted the governing instrument and investors were only given the choice to sign up or not, but not to bargain over its terms.... [T] he practical alternatives for a skeptical investor are often stark: invest without adequate protection against self-dealing or avoid the asset class altogether."); see supra note 166.

171. Strine \& Laster, supra note 21 , at 23.

172. See supra Sections III.A.2 and III.A.3. 
can be created without any negotiation in a competitive market. ${ }^{173}$ Without negotiation, private equity investors could choose to "vote with their feet" by avoiding funds that waive fiduciary duties, thereby putting competitive pressure on managers not to do so.

In this Article, I show why we cannot assume that large investors will always exert this kind of nonbargaining pressure on managers. I show that large investors may sometimes be willing to look the other way and invest in funds that have less robust protections when they can negotiate for individualized benefits. The sophistication level of other investors in the market-those that lack bargaining power-is therefore also an important consideration.

Another way of stating this idea is simply to say that large investors with bargaining power may not always be the marginal investors in the funds they invest in. This question of who the marginal investors are is a critical one. If the marginal investors are capable of evaluating LPA terms and searching the market for alternatives, ${ }^{174}$ then concerns in the literature about suboptimal LPA terms may be overstated. But if they are not, then the logic for restricting the ability to waive fiduciary standards in private equity funds would be stronger.

Strine and Laster's article made important contributions to the current dialogue on the waiver of fiduciary duties in non-corporate entities. But their commentary offered an overly narrow explanation for why private equity LPAs, specifically, are lightly negotiated (by assuming it is caused by imbalances in bargaining power) and also failed to address the role of individualized benefits in making large investors less sensitive to private equity LPA terms. By filling in these gaps, this Article clarifies both the nature and scope of the problem in the context of private equity funds.

\section{B. Federal Law: Regulating Access to Private Funds}

Federal law regulates who can and cannot invest in private entities. ${ }^{175}$ In an effort to strike an appropriate balance between investor protection and access to capital markets, policymakers have engaged in various initiatives over the years to update the rules regulating who can and cannot invest in private entities, sometimes in contradictory ways. ${ }^{176}$ On one hand, in the interest of

173. See supra Section III.B.1.

174. See supra note 126 and accompanying text.

175. See supra note 104.

176. The academic literature in this area is also mixed. Some scholars have argued that expanding private fund access to a broader universe of investors would be socially beneficial because, among other reasons, it would give ordinary investors the tax advantages of investing in a private fund and because lower regulatory restrictions could generate better expected returns. See, e.g., Samuel Brunson, Mutual Funds, Fairness, and the Income Gap, 65 ALA. L. REV. 139 (2013); John C. Coates IV, Reforming the Taxation and Regulation of Mutual Funds: A Comprehensive Legal and Economic Analysis, 1 J. Legal AnAlysis 591 (2008); Cary Martin Shelby, Privileged Access to Financial Innovation, 47 LOY. U. CHI. L.J. 315, 317 (2015) ("Retail investors are mainly stuck with mutual funds, which is an industry that is plagued with severe regulatory constraints placed on the strategies of such funds."). Other scholars have criticized the existing standards, arguing that they leave room for 
promoting investor protection, the SEC has increased various net worth requirements for participating in private markets. ${ }^{177}$ Yet, in the interest of making it easier to raise capital, Congress has also made it easier for private entities to solicit capital from a broader range of investors and authorized new channels for private investment that impose no investor sophistication standards. ${ }^{178}$

In June 2019, the SEC issued a concept release that appears to be one of the most ambitious and comprehensive re-examinations of the securities law exemptions in decades. ${ }^{179}$ This release, which is over 200 pages long, shows that the SEC is considering fundamental changes in the law to simplify, harmonize, and improve the securities offering framework. Central to this effort is a desire by the SEC - one that has been vocalized by Jay Clayton multiple times during his tenure as chairman of the $\mathrm{SEC}^{180}$ - to give ordinary investors

opportunism against unsophisticated investors. See, e.g., Abraham J.B. Cable, Mad Money: Rethinking Private Placements, 71 WASH. \& LEE L. REV. 2253, 2256-57 (proposing a re-configuration of the private placement regime because the existing rules "leave wealthy but unsophisticated investors unprotected"); Howard M. Friedman, On Being Rich, Accredited, and Undiversified, 47 OKLA. L. REV. 291, 299 (1994) (suggesting that the accredited-investor standard leaves wealthy but unsophisticated investors vulnerable); Jennifer Johnson, Private Placements: A Regulatory Blackhole, 35 DEL. J. CORP. L. 151, 191-92 nn.242-43 (2010) (arguing that "there is also a growing recognition that the accreditedinvestor standard provides insufficient protection for investors"); William K. Sjostrom, Jr., Rebalancing Private Placement Regulation, 36 SEATtLe UnIV. L. REV. 1143, 1143 (2013) (arguing that recent updates to the securities laws "has tilted the balance too far in favor of capital formation and away from investor protection"); Allen Ferrell \& John Morley, New Special Study of the Securities Markets: Institutional Intermediaries 33 (Yale Law \& Economics Research Paper No. 580, 2017), https://ssrn.com/abstract=3005542 ("[T] here are tremendous tax advantages to remaining private. The taxation of registered investment companies in the United States is almost always less favorable than the taxation of private funds, for both investors and managers.").

177. See Net Worth Standard for Accredited Investors, Securities Act Release No. 9,287, Investment Advisers Act No. 3,341, Investment Company Act No. 29,891, 77 Fed. Reg. 18684 (Dec. 21, 2011) (updating the definition of "accredited investor" so that the value of an investor's principle residence cannot be taken into consideration when determining whether the investor meets the $\$ 1$ million net worth threshold); Order Approving Adjustment for Inflation of the Dollar Amount Tests in Rule 205-3 Under the Investment Advisers Act of 1940, Investment Advisers Act Release No. 4,421, 81 Fed. Reg. 39985 (June 14, 2016) (increasing the net worth requirement for the "qualified client" standard from \$2 million to \$2.1 million). Under the Dodd-Frank Wall Street Reform and Consumer Protection Act, the SEC is required to review the definition of "accredited investor," one of the central standards for determining eligibility to invest in private vehicles, every four years and make updates as it deems appropriate. See Dodd-Frank Wall Street Reform and Consumer Protection Act, Pub. L. No. 111203, § 413(b), 124 Stat. 1376, 1577 (codified at 15 U.S.C. § 77b note (2018)); SEC, REPORT ON THE REVIEW OF THE DEFINITION OF “ACCREDITED INVESTOR” (Dec. 18, 2015), https://www.sec.gov/corpfin/reportspubs/special-studies/review-definition-of-accredited-investor-12-182015.pdf [https://perma.cc/Z264-J6NW].

178. See Jumpstart Our Business Startups Act, Pub. L. No. 112-106, tit. III, 126 Stat. 306, 315 (2012) (authorizing companies to engage in equity-based "crowdfunding" without having to satisfy any investor sophistication requirements). The final "crowdfunding" rule was finalized by the SEC in 2015. See Crowdfunding, Securities Act Release No. 9,974, Exchange Act Release No. 76,324, 80 Fed. Reg. 71388 (Nov. 16, 2015).

179. See supra note 23.

180. See, e.g., Dave Michaels, SEC Chairman Wants to Let More Main Street Investors in on Private Deals, WALl ST. J. (Aug. 30, 2018), https://www.wsj.com/articles/sec-chairman-wants-to-letmore-main-street-investors-in-on-private-deals-1535648208 [https://perma.cc/SEH2-P63G] ("Mr. Clayton said the SEC is now weighing a major overhaul of rules intended to protect mom-and-pop investors, with the goal of opening up new options for them."); Jay Clayton, Chairman, U.S. Sec. \& 
expanded access to private investment opportunities. The SEC's June 2019 release specifically contemplates potential changes that would give ordinary investors greater access to private fund investments. In December 2019, the SEC took one step in this direction by proposing to update the accredited investor definition in a manner that would allow more investors to fall within exemptions to the Securities Act of 1933 registration requirements, including by leaving income and wealth requirements unadjusted for inflation. ${ }^{181}$

The SEC's sentiment appears to be generally consistent with a report issued in November 2018 by the Committee on Capital Markets Regulation, an influential nonpartisan research group formed by Henry Paulson in 2006. ${ }^{182}$ In that report, the Committee on Capital Markets Regulation recommends expanding investor access to private equity funds in three ways: through legislative reforms to expand access to direct investments in private equity funds; through reforms to expand access to registered mutual funds that invest in private equity funds; and through reforms to make it easier for $401(\mathrm{k})$ plans to invest in private equity funds. ${ }^{183}$ The Committee on Capital Markets Regulation encourages implementing these changes on a timely basis so retail investors can enjoy access to private equity investment as quickly as possible. ${ }^{184}$

In the November 2018 report, the Committee on Capital Markets Regulation makes an important assumption about how unsophisticated investors will interact with large investors in private equity funds. To address concerns about investor safety, it suggests that if retail investors were to invest alongside large institutional investors, they would be able to free ride on the protections that those institutional investors demand, regardless of whether their investment takes the form of a direct investment, ${ }^{185}$ a registered mutual

Exch. Comm'n, Remarks on Capital Formation at the Nashville 36186 Entrepreneurship Festival (Aug. 29, 2018), https://www.sec.gov/news/speech/speech-clayton-082918 [https://perma.cc/8UES-4CME].

181. See SEC, Proposed Rule Amending the "Accredited Investor" Definition (Dec. 18, 2019), https://www.sec.gov/rules/proposed/2019/33-10734.pdf [https://perma.cc/95AD-XEYE].

182. See COMM. ON CAPITAL MKTS. Regulation, supra note 25.

183. See id. at 1 ("We find that private equity funds have a well-established performance history that justifies expanding investor access to them. We recommend three ways to do so. First, legislative reforms to expand access to direct investments in private equity funds. Second, SEC reforms to expand access to public closed-end funds that invest in private equity funds. And finally, Department of Labor reforms to facilitate the ability of $401(\mathrm{k})$ plans to invest in private equity funds.").

184. See id. at 69 ("'A[lthough our first recommendation would require legislative action, the SEC and the DOL could implement each of our other recommendations through regulatory reforms. We encourage them to do so on a timely basis, as retail investors are missing out on the returns and safety that private equity funds, and the private companies in which they invest, can offer a well-balanced portfolio.").

185. See id. at 36 ("Congress could establish or empower the SEC to establish any ... protections for retail investors that they deem necessary. For example, . . . Congress or the SEC could only permit a private equity fund to accept retail investors if the assets managed by the affiliated manager include a material institutional component (e.g., more than 50\%). Such a requirement would enable retail investors to leverage the demands of institutional investors."). 
fund, ${ }^{186}$ or a $401(\mathrm{k})$ investment. ${ }^{187}$ This assumption seems to take at face value the private equity negotiation myth-the idea that large investors in private equity funds can be relied on to demand strong protections for the other investors in a fund. ${ }^{188}$

This Article's analysis shows why policymakers should be skeptical of this claim. For the reasons outlined above, because large investors can negotiate for individualized benefits in these funds, the sophistication level of the other investors in the fund-those that do not have bargaining powermatters. ${ }^{189}$

\section{Conclusion}

The private equity industry has repeatedly invoked the private equity negotiation myth to defend against substantive critiques of fund agreements over the years. This myth assumes that large investors will use their bargaining power to demand strong fund agreement protections for all investors in a fund, but policymakers cannot simply assume that this will be true. This Article offers a more realistic portrayal of the complicated role that bargaining power plays in private equity funds. In light of active debates about the rules governing who can participate in private equity funds and how they should be operated, the need for sound theory - and not mythologies promulgated by the industry - in this area has never been stronger.

186. See id. at 42 ("To the extent additional protections for retail investors were deemed appropriate, we note that the SEC could adopt such protections by simply restricting the private equity funds that public closed-end funds could invest in. For example, the SEC could only allow public closed-end funds to invest in private equity funds . . . where the assets managed by the affiliated manager include a material institutional component (e.g., more than 50\%).”).

187. See id. at 67-68 ("The investment committee should only invest in private equity funds where ... at least a majority of [its] assets were managed on behalf of third party investors (other than defined contribution plans) that are qualified institutional buyers within the meaning of Rule 144A as promulgated under Securities Exchange Act of 1933, as amended.").

188. The November 2018 report does not discuss giving retail investors a most favored nation right or other feature that would entitle them to receive benefits granted to other investors.

189. In addition to concerns about manager self-dealing, retail investors would also need to be concerned about managers transferring value to larger investors. In an earlier article, I discussed factors that dis-incentivize managers from transferring too much value from pooled funds to separately managed accounts and co-investment vehicles. See William Clayton, Preferential Treatment and the Rise of Individualized Investing, 11 VA. L. \& BUS. REV. 249 (2017). Nearly all of those factors, however, rely on smaller investors being capable of analyzing complex disclosures and making informed investment decisions - an assumption that is less likely to be true of retail investors. 
VI. Appendices

Appendix A

Typical Stage in Investment Cycle at Which GPs

Offer Co-Investment Rights to LPS

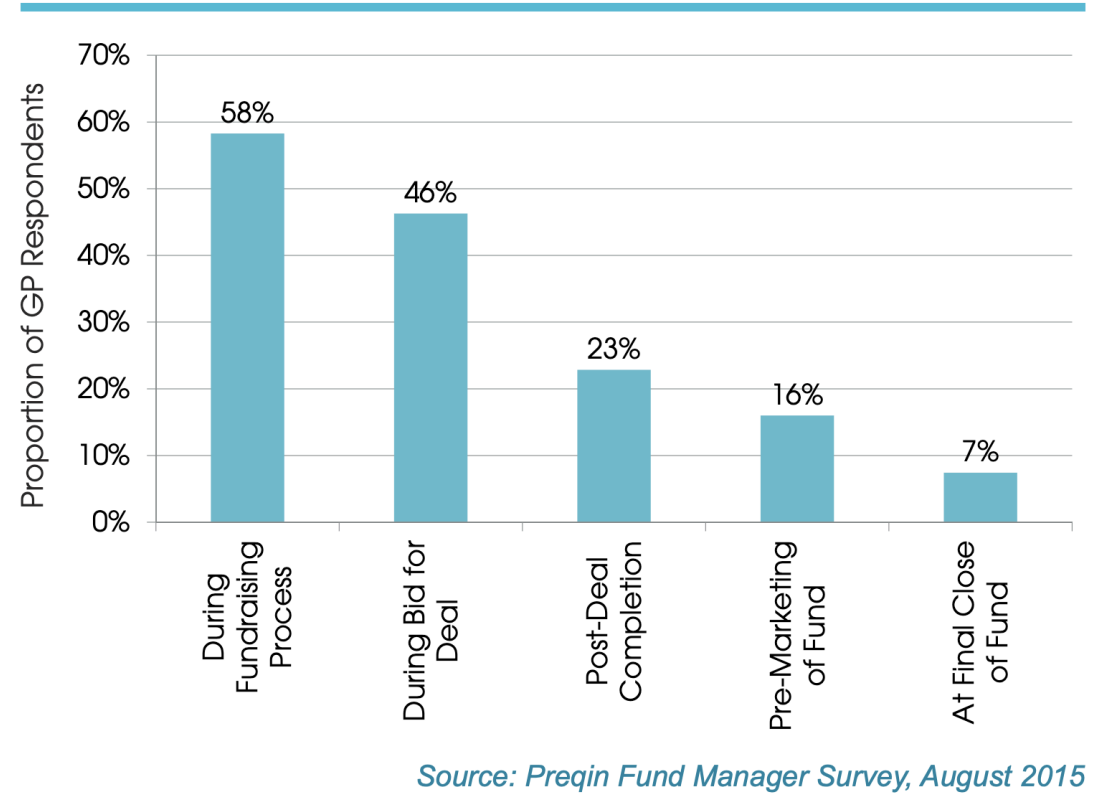

Reprinted from Preqin, Private Equity Co-InVestment Outlook 5 fig.6 (Nov. 2015) 
Appendix B. Illustrative Co-Investment Arrangement (arrows pointing directly at portfolio companies denote co-investments)

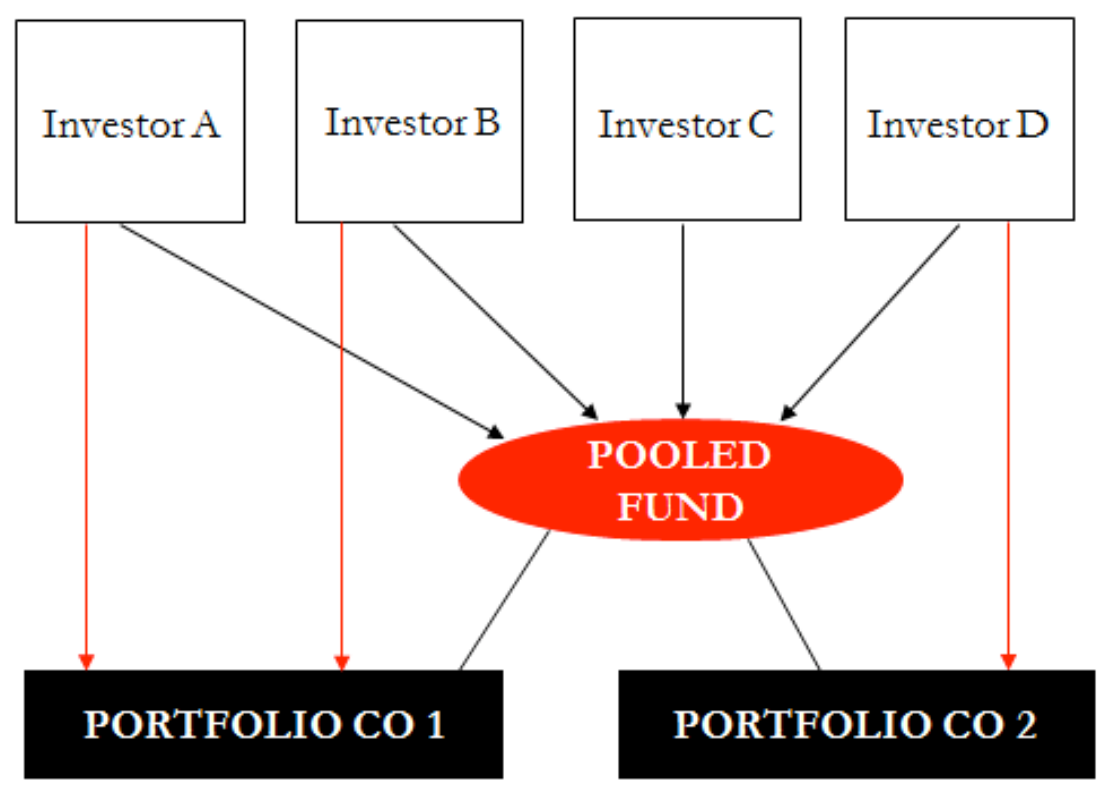

